University of South Florida

DIGITAL COMMONS

Digital Commons @ University of

@ UNIVERSITY OF SOUTH FLORIDA

South Florida

$1-1-2016$

\title{
2016 Accountability Report USF System
}

USF

Follow this and additional works at: https://digitalcommons.usf.edu/usf_accountability_reports

\section{Scholar Commons Citation}

USF, "2016 Accountability Report USF System" (2016). USF Accountability Reports. 59.

https://digitalcommons.usf.edu/usf_accountability_reports/59

This Article is brought to you for free and open access by the USF Archives at Digital Commons @ University of South Florida. It has been accepted for inclusion in USF Accountability Reports by an authorized administrator of Digital Commons @ University of South Florida. For more information, please contact digitalcommons@usf.edu. 


\section{5-16}

\section{Annual Accountability Report}

\section{UNIVERSITY OF}

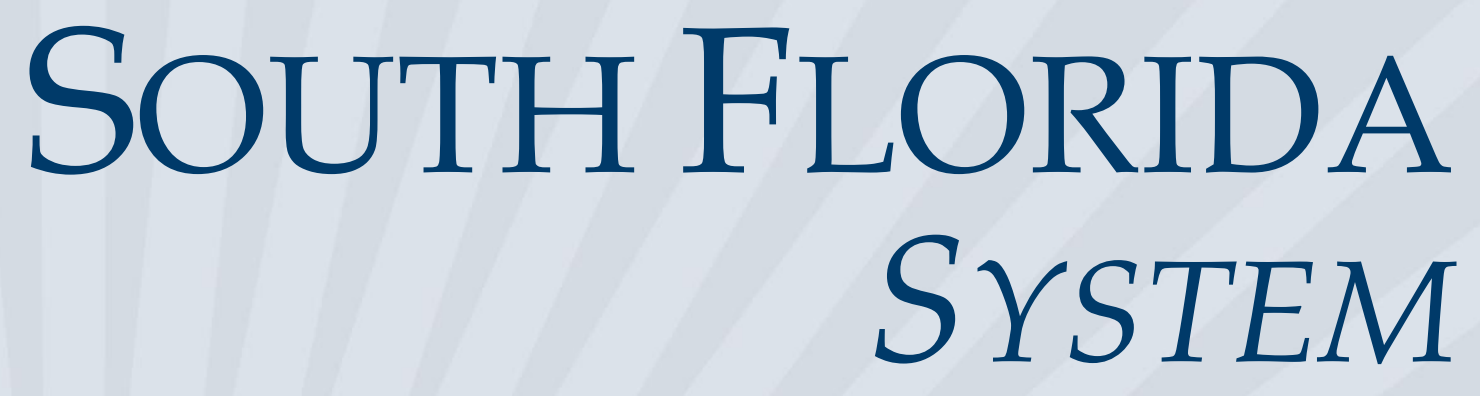

STATE UNIVERSITY SYSTEM of FLORIDA Board of Governors 


\section{$\underline{\text { TABLE OF CONTENTS }}$}

\section{E EXECUTIVE SUMMARY}

DASHBOARD

p. 2

PERFORMANCE FUNDING METRICS

p. 5

KEY ACHIEVEMENTS

p. 6

NARRATIVE

p. 7

\section{DATA TABLES}

SECTION 1. FINANCIAL RESOURCES p. 14

SECTION 2. PERSONNEL

p. 18

SECTION 3. ENROLLMENT

p. 19

SECTION 4. UNDERGRADUATE EDUCATION

p. 23

SECTION 5. GRADUATE EDUCATION

p. 32

SECTION 6. RESEARCH \& ECONOMIC DEVELOPMENT

p. 35 


\section{Dashboard}

\begin{tabular}{|c|c|c|c|c|c|c|c|c|}
\hline $\begin{array}{l}\text { Headcount } \\
\text { Enrollments }\end{array}$ & $\begin{array}{l}\text { Fall } \\
2015\end{array}$ & $\begin{array}{c}\% \\
\text { Total }\end{array}$ & $\begin{array}{l}\text { 2014-2015 } \\
\% \text { Change }\end{array}$ & \multicolumn{3}{|c|}{ Degree Programs Offered } & \multicolumn{2}{|c|}{2012 Carnegie Classifications } \\
\hline TOTAL & 48,984 & $100 \%$ & $1 \%$ & \multicolumn{2}{|c|}{ TOTAL (as of Sprina 2016) } & 306 & \multirow{2}{*}{ Basic: } & \multirow{10}{*}{$\begin{array}{l}\text { The USF System is } \\
\text { not classified by the } \\
\text { Carnegie Foundation. } \\
\text { The individual campus } \\
\text { reports provide these } \\
\text { classifications. }\end{array}$} \\
\hline White & 26,002 & $53 \%$ & $-2 \%$ & Baccalaureate & & 115 & & \\
\hline Hispanic & 8,605 & $18 \%$ & $3 \%$ & Master's & & 142 & \multirow{2}{*}{$\begin{array}{c}\text { Undergraduate } \\
\text { Instructional Program: }\end{array}$} & \\
\hline Black & 4,666 & $10 \%$ & $-2 \%$ & Research Doctorate & & 45 & & \\
\hline Other & 9,711 & $20 \%$ & $10 \%$ & Professional Doctore & & 4 & \multirow{2}{*}{$\begin{array}{c}\text { Graduate } \\
\text { Instructional Program: }\end{array}$} & \\
\hline Full-Time & 33,614 & $69 \%$ & $2 \%$ & \multirow{2}{*}{$\begin{array}{c}\text { Faculty } \\
\text { (Fall 2015) }\end{array}$} & \multirow{2}{*}{$\begin{array}{l}\text { Full- } \\
\text { Time }\end{array}$} & \multirow{2}{*}{$\begin{array}{l}\text { Part- } \\
\text { Time }\end{array}$} & & \\
\hline Part-Time & 15,370 & $31 \%$ & $-3 \%$ & & & & \multirow{2}{*}{ Size and Setting: } & \\
\hline Undergraduate & 35,990 & $73 \%$ & $1 \%$ & TOTAL & 1,954 & 812 & & \\
\hline Graduate & 10,698 & $22 \%$ & $1 \%$ & Tenure \& Ten. Track & 1,134 & 41 & \multirow{2}{*}{$\begin{array}{l}\text { Community } \\
\text { Engagement: }\end{array}$} & \\
\hline Unclassified & 2,296 & $5 \%$ & $4 \%$ & Non-Tenured Faculty & 820 & 771 & & \\
\hline
\end{tabular}

\section{DEGREE PRODUCTIVITY AND PROGRAM EFFICIENCY}
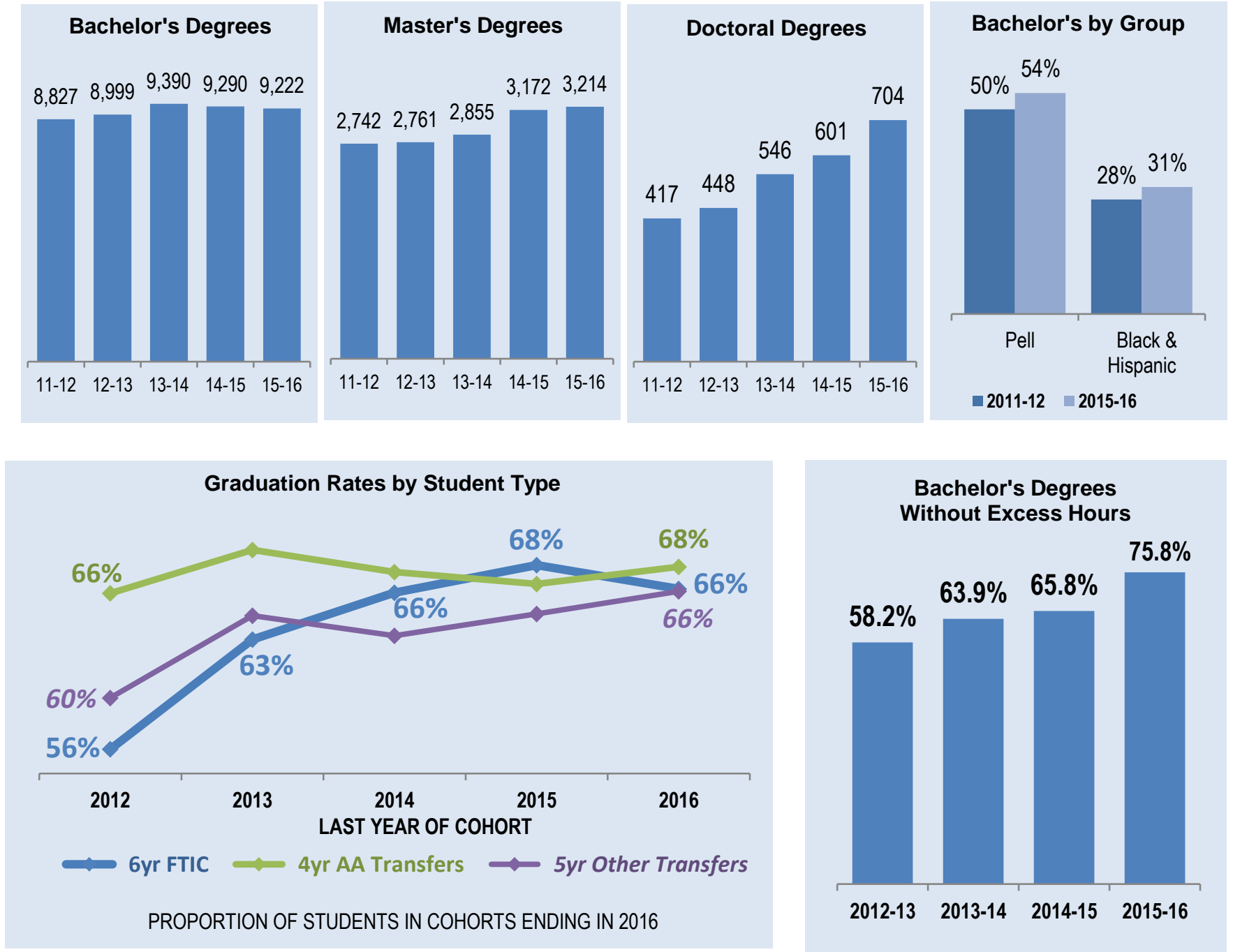


\section{Dashboard}

DEGREES AWARDED IN PROGRAMS OF STRATEGIC EMPHASIS

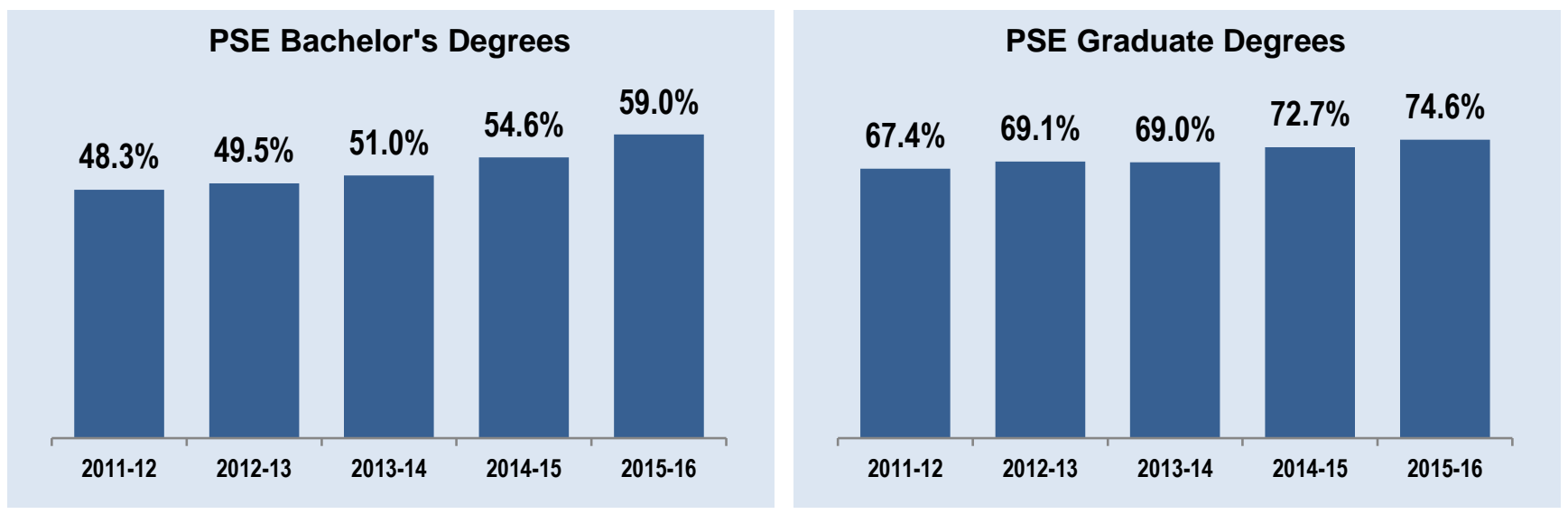

RESEARCH AND COMMERCIALIZATION ACTIVITY

Total R\&D Expenditures (\$ Millions) with Percent Funded Externally

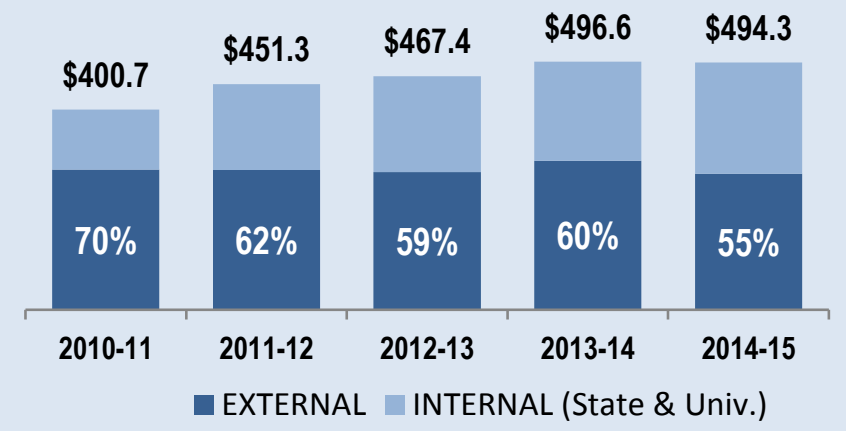

Licenses and Licensing Revenue

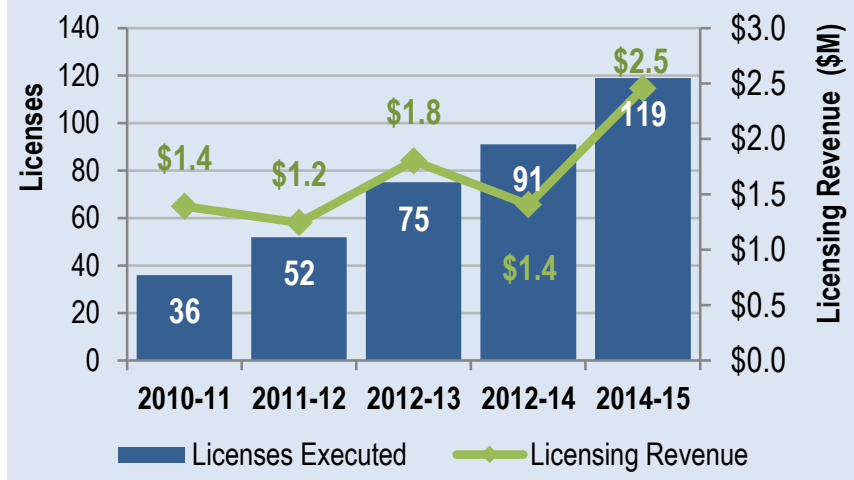

\section{RESOURCES}

\section{ACTUAL FUNDING PER FTE}

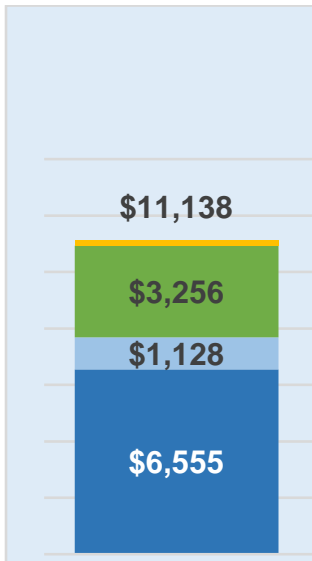

2011-12

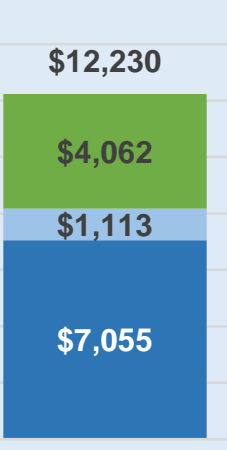

2013-14
$\$ 13,271$

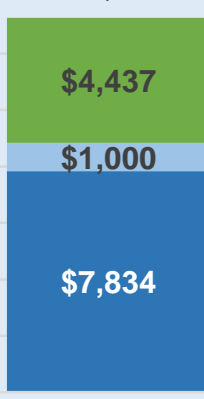

2014-15
$\$ 13,736$

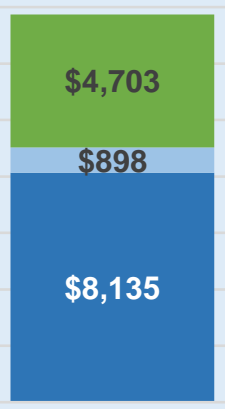

2015-16
- Tuition \& Fees (from Student)

- State-funded Financial Aid (to the Student)

\section{- Other Trust Funds}

- State Appropriation (GR \& Lottery)
Note: Tuition and Fee revenues include tuition, tuition differential fee and $E \& G$ fees (i.e. application, late registration, and library fees/fines) based on the actual amount collected (not budget authority) by universities as reported in their Operating Budget 625 reports. Other local fees that do not support $E \& G$ activities are not included here. Please note that a portion of the Tuition \& Fees is supported by federal SFA programs (ie, Pell grants). State-funded Student Financial Aid amounts include the 11 SFA programs that OSFA reports annually. State Appropriations includes General Revenues, Lottery and Other Trust funds (i.e., Federal Stimulus for 2009-10 and 2010-11 only) that are directly appropriated to the university as reported in Final Amendment Package. Student FTE are actual and based on the standard IPEDS definition of FTE (equal to 30 credit hours for undergraduates and 24 for graduates).

This data does not include funds or FTE from special units (i.e., IFAS, Health-Science Centers or Medical Schools). Not adjusted for inflation. 


\section{Dashboard}

\section{POST-GRADUATION METRICS}

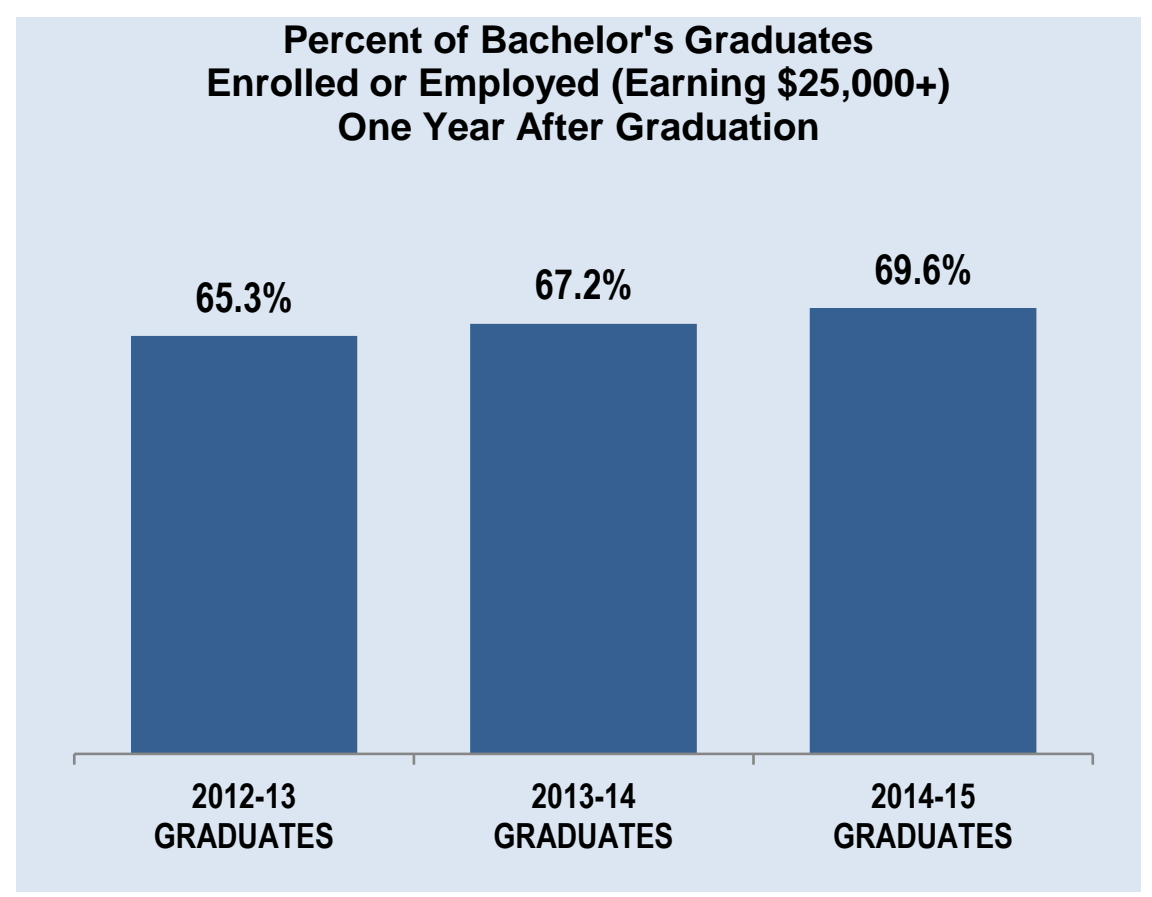

\section{Wages of Full-time Employed in Florida Baccalaureates One Year After Graduation 5th, 25th, 50th, 75th and 95th Percentiles}

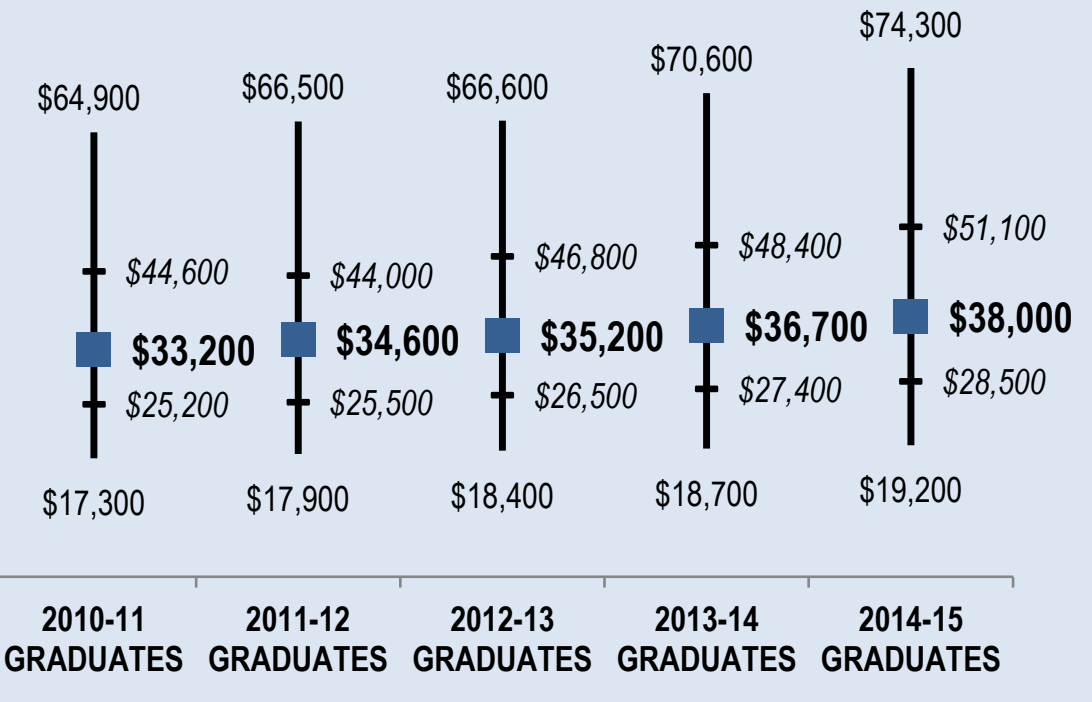

Notes: Percentages are based on the number of recent baccalaureate graduates who are either employed full-time or continuing their education in the U.S. (based on the National Student Clearinghouse data). Full-time employment is based on those who earned more than a full-time (40hrs a week) worker making minimum wage. Due to limitations in the data, the continuing enrollment data includes any enrollment the following year regardless of whether the enrollment was post-baccalaureate or not. Board of Governors staff found 93\% of the total $2014-15$ graduating class.

See Table 40 within this report for additional information about this metric.

Notes: Wage data is based on annualized Unemployment Insurance (UI) wage data for those graduates who earned more than a full-time employee making minimum wage in the fiscal quarter a full year after graduation. This UI wage data does not include individuals who are selfemployed, employed by the military or federal government, or those without a valid social security number. In 2014-15, these data accounted for $60 \%$ of the total graduating class. This wage data includes graduates who were employed full-time (regardless of their continuing enrollment). Wages are provided for 5th, 25th, 50th, 75th and 95th percentiles. Median wages are identified by bolded values. The interquartile range (shown in italics) represents $50 \%$ of the wage data. Wages rounded to nearest hundreds. 


\section{Performance Based Funding Metrics}

\begin{tabular}{|c|c|c|c|c|}
\hline & & 2013-14 & 2014-15 & CHANGE \\
\hline \multirow[t]{2}{*}{1} & $\begin{array}{l}\text { Percent Employed }(\$ 25,000+) \text { or Enrolled } \\
\text { One Year After Graduation }\end{array}$ & $67.2 \%$ & $69.6 \%$ & $2.4 \%$ \\
\hline & & 2013-14 & 2014-15 & CHANGE \\
\hline \multirow[t]{2}{*}{2} & $\begin{array}{l}\text { Median Wages of Bachelor's Graduates } \\
\text { Employed Full-time One Year After Graduation }\end{array}$ & $\$ 36,700$ & $\$ 38,000$ & $3.5 \%$ \\
\hline & & 2011-15 & $2012-16$ & CHANGE \\
\hline \multirow[t]{2}{*}{3} & $\begin{array}{l}\text { Cost to the Student: Net Tuition \& Fees per } 120 \\
\text { Credit Hours }\end{array}$ & $\$ 13,540$ & $\$ 13,170$ & $-2.7 \%$ \\
\hline & & 2009-15 & $2010-16$ & CHANGE \\
\hline \multirow[t]{2}{*}{4} & $\begin{array}{l}\text { Six-Year Graduation Rate for } \\
\text { First-time-in-College (FTIC) Students }\end{array}$ & $67.75 \%$ & $66.3 \%$ & $-1.5 \%$ \\
\hline & & 2014-15 & $2015-16$ & CHANGE \\
\hline \multirow[t]{2}{*}{5} & Academic Progress Rate & $85.05 \%$ & $86.14 \%$ & $1.1 \%$ \\
\hline & & $2014-15$ & $2015-16$ & CHANGE \\
\hline \multirow[t]{2}{*}{6} & $\begin{array}{l}\text { Bachelor's Degrees Awarded } \\
\text { within Programs of Strategic Emphasis }\end{array}$ & $54.59 \%$ & $58.99 \%$ & $4.4 \%$ \\
\hline & & FALL 2014 & FALL 2015 & CHANGE \\
\hline \multirow[t]{2}{*}{7} & University Access Rate & $43.01 \%$ & $41.21 \%$ & $-1.8 \%$ \\
\hline & & 2014-15 & $2015-16$ & CHANGE \\
\hline \multirow[t]{2}{*}{8} & $\begin{array}{l}\text { Graduate Degrees Awarded } \\
\text { within Programs of Strategic Emphasis }\end{array}$ & $72.67 \%$ & $74.60 \%$ & $1.9 \%$ \\
\hline & & $2014-15$ & $2015-16$ & CHANGE \\
\hline \multirow[t]{2}{*}{9} & $\begin{array}{l}\text { Board of Governors Choice Metric: } \\
\text { Bachelor's Degrees Without Excess Hours }\end{array}$ & $65.77 \%$ & $75.58 \%$ & $9.8 \%$ \\
\hline & & FALL 2013 & FALL 2014 & CHANGE \\
\hline 10 & $\begin{array}{l}\text { Board of Trustees Choice Metric: } \\
\text { Number of post-doctoral appointees }\end{array}$ & 321 & 300 & $-6.5 \%$ \\
\hline
\end{tabular}




\section{Key Achievements (2015-2016)}

\section{STUDENT AWARDS/ACHIEVEMENTS}

1. The USF System was home to 50 national scholarship winners and fellowship student awardees during the 2015-16 academic year including Boren, Fulbright, Gilman, and Goldwater.

2. USFSM welcomed its first Fulbright scholar, Nefike Gunden, a master's student in Hospitality and Tourism Management.

3. Research on the impact of climate change led USFSP graduate student Adam Flanery to Cameroon on a 20-day trip to collect thesis data on the forest communities in the country's southwest region.

\section{FACULTY AWARDS/ACHIEVEMENTS}

1. Dr. Kathy Black, Professor of Social Work at USFSM, was named the director of Age-Friendly Sarasota and addressed a committee of the World Health Organization in Geneva, Switzerland, through a presentation about the multi-partner initiative to make Sarasota County friendlier for people across their lifespans.

2. Drs. Kathryn and John Arthur of USFSP made an anthropological discovery of an ancient skeleton in the highlands of Ethiopia and it was confirmed by scientists at Cambridge University to contain the world's first, complete African genome - news that was covered by Science, the National Science Foundation and The New York Times, among other publications.

3. USF Tampa microbiologist Dr. Lindsey N. Shaw and USF chemistry professor Dr. Bill Baker discovered an Antarctic Sponge Extract that can help kill MRSA.

\section{PROGRAM AWARDS/ACHIEVEMENTS}

1. USF was ranked \#1 Best College for Veterans by Military Times (2016), up from \#2 in 2015's rankings.

2. Using data reported by the National Center for Education Statistics (NCES), AffordableSchools.net ranked USFSP in its "25 Most Exclusive Public Bachelor's College by Admission Rate", alongside the U.S. Naval Academy, the University of California Berkeley and the University of North Carolina at Chapel Hill.

3. USFSM opened a Student Veteran Success Center supported by an anonymous $\$ 50,000$ donation.

\section{RESEARCH AWARDS/ACHIEVEMENTS}

1. Dr. James McHale, director of the USFSP Family Study Center, and his team were awarded a $\$ 2.9$ million grant from the National Institutes of Health $(\mathrm{NIH})$ to examine the role of co-parenting and family group dynamics.

2. USF ranks $9^{\text {th }}$ in the nation among public universities and $21^{\text {st }}$ worldwide for granted U.S. patents among all universities according to the Intellectual Property Owners Association/NAI. In 2015/16 USF registered 105 new patents, 133 licenses/options, and nine new startups.

3. Dr. Fawn Ngo, Associate Professor of Criminology, USFSM, was named editor of a criminologist journal.

\section{INSTITUTIONAL AWARDS/ACHIEVEMENTS}

1. USFSP marked the mid-point of construction (topping-out) of the Kate Tiedemann College of Business with a $\$ 1$ million gift from businesswoman Ellen Cotton, followed closely by a $\$ 5$ million gift from former Raymond James executive Lynn Pippenger.

2. USF Tampa was designated as a Florida Emerging Preeminent Research University in June 2016. 


\section{Narrative}

Limit narrative to one page per section (a 9pg max). Arial 11 point font.

\section{Teaching and Learning}

\section{STRENGTHEN QUALITY AND REPUTATION OF ACADEMIC PROGRAMS AND UNIVERSITIES}

USF Tampa continues to strengthen the quality and reputation of our programs - evidenced by the record setting fall FTIC student profile. With SAT scores of 1226/HS and an average GPA of 4.08, this is the highest achieving freshman class in USF history.

To better serve the higher education needs of our surrounding communities USFSM established a College of Science \& Mathematics (CSM), realigning four colleges and strengthening the quality of academic programs. Additionally, the new College of Liberal Arts \& Social Sciences includes three distinct areas: a School of Education, a Department of Liberal Arts, and a Department of Social Sciences. The combination of these three departments will provide hands-on research and learning opportunities at the undergraduate and graduate levels.

The department of Journalism and Media Studies at USFSP received accreditation for its new Digital Journalism and Design Program by The Accrediting Council on Education in Journalism and Mass Communication (ACEJMC), making it one of fewer than 10 programs nationally to have the accreditation. At the same time, ACEJMC re-accredited the existing bachelor's and traditional master's degrees.

\section{INCREASE DEGREE PRODUCTIVITY AND PROGRAM EFFICIENCY}

The USF System is highly ranked in the SUS for employment, with nearly 78 percent of undergraduates employed (full-time) or enrolled one year after graduation. USF System is also a leader in median wages at $\$ 38,000$.

In November 2015, USFSP opened a new Military Veterans Success Center, serving an estimated 300 student veterans, active military and dependents.

At USFSM students are benefitting from a new personal system of advising that includes a "Career Success Map" and teams of professionals to guide them during their education, assist with job choices, and help as they transition toward meaningful new careers. This career-centric approach to student advising showcases the commitment to high levels of excellence and career preparedness that is part of the fabric of all institutions throughout the USF System.

\section{INCREASE THE NUMBER OF DEGREES AWARDED IN S.T.E.M. AND OTHER PROGRAMS OF STRATEGIC EMPHASIS}

USF System continues to be a leader in the state for degrees awarded in Areas of Strategic Emphasis, with 59 percent of the USF System's undergraduate degrees and 74 percent of our graduate degrees awarded in areas of strategic emphasis, including 40 percent in STEM in 2015-16.

In spring 2016, the USFSM College of Science and Mathematics (CSM) and USF Tampa's College of Engineering partnered to develop a 2+2 pathway for aspiring engineering students, while, USFSP added new concentrations in Healthcare and Business Analytics to their highly ranked MBA program. 


\section{Narrative}

\section{Scholarship, Research, and Innovation}

STRENGTHEN QUALITY AND REPUTATION OF SCHOLARSHIP, RESEARCH, AND INNOVATION

USF Tampa is classified by the Carnegie Foundation for Advancement of Teaching in the Doctoral Universities: Highest Research Activity category, a distinction shared by only 2.5 percent of all universities.

In order to assist in the identification, securing and administering of the scholarly, research, and innovation initiatives USFSM has hired a grant support specialist, along with the continued appointment of a research coordinator. USFSP has developed a new Minority Post-Doctoral Program to increase diversity among faculty while providing research support to current team members.

USFSP professor of Psychology, Dr. V. Mark Durand, was elected President of the American Psychological Association's Division 33. This division focuses on Intellectual and Developmental Disabilities/Autism Spectrum Disorder (ASD).

\section{INCREASE RESEARCH AND COMMERCIALIZATION ACTIVITY}

As a leading metropolitan research university in the State of Florida, USF is dedicated to high-impact research and innovation. A commitment realized in the USF Tampa Bay Technology Incubator which is home to over 60 companies with $\$ 73.2 \mathrm{M}$ in funding, $\$ 37.1 \mathrm{M}$ in sales, and 230 jobs created. Additionally, the USF Innovation Enterprise infuses $\$ 400$ Million yearly into Florida's economy.

Further affirming our dedication; is the USFSP Geo-Spatial Analytics Lab, under the leadership of Dr. Barnali Dixon, which was commissioned to provide a complete analysis of vegetation and habitat change within the Seminole Tribe reservation of Florida from 1940 to 2014, using GIS and remote sensing techniques.

While USFSM formed a consortium with New College of Florida Manatee-Sarasota, Ringling College of Art and Design, and Eckerd College. This newly formed Consortium of Colleges on the Creative Coast (C4) is pursuing opportunities to collaboratively increase research and commercialization.

\section{INCREASE COLLABORATION AND EXTERNAL SUPPORT FOR RESEARCH ACTIVITY}

The College of Business at USFSM engaged with local businesses, and non-profits to allow their students the opportunity for hands-on research and valuable experience. From marketing studies to the development of business plans, students work side-by-side with the businesses to fill the needs of the community while also developing connections with the community, and experience they can add to their resumes.

James McHale, director of the USFSP Family Study Center, was funded for $\$ 395,680$ by the Juvenile Welfare Board of Pinellas County to support the work of infant family mental health. McHale also received approximately $\$ 40,000$ from Pinellas County to support the efforts.

With seven teams selected, USF Tampa ranked $1^{\text {st }}$ in Florida (and $3^{\text {rd }}$ in the nation behind the University of Michigan and Georgia Tech), in the National Science Foundation's (NSF) I-Corps program which translates technology into commercial products. 


\section{Narrative}

\section{Community and Business Engagement}

\section{STRENGTHEN QUALITY AND REPUTATION OF COMMITMENT TO COMMUNITY AND BUSINESS} ENGAGEMENT

USFSM established an Office of Community Engagement to cultivate strategic partnerships throughout the region including government entities, schools, non-profits, service clubs, local businesses, and community organizations.

Working closely with the City of St. Petersburg, USFSP's Sustainability Office created a Climate Action Plan, pledging to reduce baseline Greenhouse Gas emissions by 50 percent by 2035 and to achieve carbon neutrality by 2050 .

USF Tampa has been recognized as a "Top Producer" of Peace Corps Volunteers, ranking $16^{\text {th }}$ in the Nation (among universities larger than 15K) for Peace Corps Volunteers in 2016.

\section{INCREASE LEVELS OF COMMUNITY AND BUSINESS ENGAGEMENT}

The Florida Legislature named the Center for Partnerships for Arts-Integrated Teaching (PAInT) at USFSM as a state-wide Center in Florida. PAInT partners with the Circus Arts Conservatory, a 501c3 located in Sarasota and currently serves approximately 4,000 students and continues to strengthen STEM education.

USF Tampa has established the largest P3 (public, private partnership) in the history of the SUS, by announcing the construction of The Village, a new student housing project on the USF campus. This district will be home to over 2,000 students, recreation facilities, as well as a Publix grocery store.

USFSP has expanded its role in St. Petersburg's new Innovation District. Regional Chancellor Wisniewska was named President, leading District partners through a strategic planning process to include identifying opportunities for growth, a signage and way-finding program and branding.

\section{INCREASE COMMUNITY AND BUSINESS WORKFORCE}

A total of 162 employers were on the USFSP campus during 2015-2016, taking part in events, programs, and job fairs in collaboration with the Career Center, representing a 2 percent increase over 2014-15.

Continuing their efforts to ensure that graduates are well-prepared for the workforce, USF Tampa implemented new programs such as; Suit-A-Bull, a free suit rental service for students, Handshake a career services platform that allows students and employers to connect seamlessly and Revature, a leading technology talent development company, that provides online Coding programs to all USF System students and alumni.

USFSM leverages community partnerships to bridge the gap between the classroom and the workforce. As an example, the ongoing collaboration between Mote Marine Laboratory, a worldrenowned aquarium and research center, and the USF Sarasota-Manatee Biology program focuses on the discovery process and a learning environment that engages students outside of the classroom. 


\section{Data Tables}

\section{FINANCIAL RESOURCES}

Table 1A. Education and General Revenues

Table 1B. Education and General Expenditures

Table 1C. Funding per Student FTE

Table 1D. Cost per Degree [Revised]

Table 1E. Other Budget Entities

Table 1F. Voluntary Support of Higher Education

PERSONNEL

Table 2A. Personnel Headcount

\section{ENROLLMENT}

Table 3A. Headcount Enrollment by Student Type [Revised]

Table 3B. Full-time Equivalent (FTE) Enrollment [Revised]

Table 3C. Enrollment by Instructional Method [Revised]

Table 3D. Headcount Enrollment by Military Status and Student Level

Table 3E. University Access Rate: Undergraduate Enrollment with Pell Grant

\section{UNDERGRADUATE EDUCATION}

Table 4A. Baccalaureate Degree Program Changes in AY 2015-2016

Table 4B. Retention Rates

Table 4C. First-Time-in-College (FTIC) Six-Year Graduation Rates (Full-time only)

Table 4D. FTIC Graduation Rates (Full- and Part-time)

Table 4E. AA Transfers Graduation Rates

Table 4F. Other Transfers Graduation Rates

Table 4G. Baccalaureate Degrees Awarded

Table 4H. Baccalaureate Degrees Awarded in Areas of Strategic Emphasis

Table 4I. Baccalaureate Degrees Awarded to Underrepresented Groups

Table 4J. Baccalaureate Degrees Without Excess Credit Hours

Table 4K. Undergraduate Course Offerings

Table 4L. Faculty Teaching Undergraduates

Table 4M. Student/Faculty Ratio

Table 4N. Licensure/Certification Exam: Nursing

Table 4O. Post-Graduation Metrics [Revise?]

\section{GRADUATE EDUCATION}

Table 5A. Graduate Degree Program Changes in AY 2015-2016

Table 5B. Graduate Degrees Awarded

Table 5C. Graduate Degrees Awarded in Areas of Strategic Emphasis

Table 5D. Licensure/Certification Exams: Graduate Programs

\section{RESEARCH \& ECONOMIC DEVELOPMENT}

Table 6A. Research and Development Expenditures

Table 6B. Centers of Excellence 


\section{Section 1 - Financial Resources}

TABLE 1A. University Education and General Revenues

\begin{tabular}{|c|c|c|c|c|c|}
\hline & $\begin{array}{r}2012-13 \\
\text { Actual }\end{array}$ & $\begin{array}{r}2013-14 \\
\text { Actual }\end{array}$ & $\begin{array}{r}2014-15 \\
\text { Actual }\end{array}$ & $\begin{array}{r}2015-16 \\
\text { Estimates }\end{array}$ & $\begin{array}{r}2016-17 \\
\text { Estimates }\end{array}$ \\
\hline \multicolumn{6}{|l|}{ MAIN OPERATIONS } \\
\hline Recurring State Funds & $\$ 230,779,497$ & $\$ 248,172,676$ & $\$ 276,107,424$ & $\$ 269,856,524$ & $\$ 276,143,999$ \\
\hline Non-Recurring State Funds & $-\$ 48,242,853$ & $\$ 4,203,604$ & $\$ 2,066,536$ & $\$ 24,966,845$ & $\$ 34,808,363$ \\
\hline Tuition & $\$ 141,487,748$ & $\$ 148,736,779$ & $\$ 156,109,761$ & $\$ 164,385,077$ & $\$ 178,059,907$ \\
\hline Tuition Differential Fee & $\$ 33,908,713$ & $\$ 33,418,653$ & $\$ 33,242,501$ & $\$ 34,039,814$ & $\$ 34,440,300$ \\
\hline Misc. Fees \& Fines & $\$ 2,810,903$ & $\$ 2,969,679$ & $\$ 3,698,982$ & $\$ 4,558,890$ & $\$ 4,513,532$ \\
\hline Phosphate/Other TF & $\$ 0$ & $\$ 0$ & $\$ 0$ & $\$ 0$ & $\$ 0$ \\
\hline SUBTOTAL & $\$ 360,744,008$ & $\$ 437,501,391$ & $\$ 471,225,204$ & $\$ 497,807,150$ & $\$ 527,966,101$ \\
\hline \multicolumn{6}{|c|}{ HEALTH SCIENCE CENTER / MEDICAL SCHOOL } \\
\hline Recurring State Funds & $\$ 65,793,008$ & $\$ 71,529,136$ & $\$ 72,577,386$ & $\$ 72,910,072$ & $\$ 74,243,025$ \\
\hline Non-Recurring State Funds & $\$ 0$ & $\$ 1,409,562$ & $\$ 2,100,000$ & $\$ 1,000,000$ & $\$ 250,000$ \\
\hline Tuition & $\$ 48,203,644$ & $\$ 51,733,993$ & $\$ 47,109,158$ & $\$ 51,663,328$ & $\$ 61,002,027$ \\
\hline Tuition Differential Fee & $\$ 2,956,633$ & $\$ 3,248,580$ & $\$ 3,339,071$ & $\$ 3,282,304$ & $\$ 3,288,193$ \\
\hline Misc. Fees \& Fines & $\$ 41,978$ & $\$ 83,414$ & $\$ 107,281$ & $\$ 389,424$ & $\$ 407,400$ \\
\hline Phosphate/Other TF & $\$ 0$ & $\$ 0$ & $\$ 0$ & $\$ 0$ & $\$ 0$ \\
\hline SUBTOTAL & $\$ 116,995,263$ & $\$ 128,004,685$ & $\$ 125,232,896$ & $\$ 129,245,128$ & $\$ 139,190,645$ \\
\hline TOTAL & $\$ 477,739,271$ & $\$ 565,506,076$ & $\$ 596,458,100$ & $\$ 627,052,278$ & $\$ 667,156,746$ \\
\hline
\end{tabular}

Recurring State Funds: include general revenue and lottery education \& general $(E \& G)$ appropriations and any administered funds provided by the state, including annual adjustments of risk management insurance premiums for the estimated year. This does not include technical adjustments or transfers made by universities after the appropriation. Please note: 2013-14 revenues include the non-recurring $\$ 300 \mathrm{M}$ system budget reduction. Sources: SUS Final Amendment Packages were used for actual years; and, the latest SUS University Conference Report and various workpapers were used for the estimated year. Non-Recurring State Funds: include general revenue and lottery education \& general appropriations and any administered funds provided by the state. This does not include technical adjustments or transfers made by Universities after the appropriation. Source: non-recurring appropriations section of the annual Allocation Summary and Workpapers that include all other non-recurring budget amendments allocated later in the fiscal year. Note on Performance Funding: the State investment piece of performance funding is reported in the 'Non-Recurring State Funds' and the Institutional investment piece is reported within 'Recurring State Funds'. Tuition: Actual resident \& non-resident tuition revenues collected from students, net of fee waivers. Source: Operating Budget, Report 625 - Schedule I-A. Tuition Differential Fee: Actual tuition differential revenues collected from undergraduate students. Source: Operating Budget, Report 625 - Schedule I-A. Miscellaneous Fees \& Fines: Other revenue collections include items such as application fees, late registration fees, library fines, miscellaneous revenues. This is the total revenue from Report 625 minus tuition and tuition differential fee revenues. This does not include local fees. Source: Operating Budget, Report 625 - Schedule I-A. Phosphate/Other Trust Fund: State appropriation for the Florida Industrial and Phosphate Research Institute at the University of South Florida (for history years through 2012-13); beginning 2013-14 the Phosphate Research Trust Fund is appropriated through Florida Polytechnic University. Other Operating Trust Funds. For UF-IFAS and UF-HSC, actual revenues from the Incidental Trust Funds and Operations \& Maintenance Trust Fund are provided by the University of Florida. Source: Final Amendment Package. This data is not adjusted for inflation. 


\section{Section 1 - Financial Resources (continued)}

TABLE 1B. University Education and General Expenditures (Dollars in Millions)

\begin{tabular}{lrrrrr} 
& $\mathbf{2 0 1 1 - 1 2}^{*}$ & $\mathbf{2 0 1 2 - 1 3}$ & $\mathbf{2 0 1 3 - 1 4}$ & $\mathbf{2 0 1 4 - 1 5}$ & $\mathbf{2 0 1 5 - 1 6}$ \\
\hline MAIN OPERATIONS & & & & & \\
\hline Instruction/Research & $\$ 237,707,579$ & $\$ 287,236,489$ & $\$ 291,847,040$ & $\$ 306,815,335$ & $\$ 327,426,088$ \\
\hline Administration and Support & $\$ 23,893,443$ & $\$ 32,410,560$ & $\$ 30,296,584$ & $\$ 36,591,191$ & $\$ 43,525,885$ \\
\hline PO\&M & $\$ 35,141,676$ & $\$ 41,615,990$ & $\$ 39,965,797$ & $\$ 44,188,957$ & $\$ 52,794,254$ \\
\hline Student Services & $\$ 18,207,622$ & $\$ 16,781,322$ & $\$ 12,004,895$ & $\$ 26,773,012$ & $\$ 28,949,026$ \\
\hline Library/Audio Visual & $\$ 13,297,996$ & $\$ 10,411,967$ & $\$ 14,004,521$ & $\$ 14,235,047$ & $\$ 14,978,164$ \\
\hline Other & $\$ 6,470,660$ & $\$ 6,957,842$ & $\$ 5,869,392$ & $\$ 7,862,423$ & $\$ 8,531,424$ \\
\hline SUBTOTAL & $\$ 334,718,976$ & $\$ 395,414,170$ & $\$ 393,988,229$ & $\$ 436,465,965$ & $\$ \mathbf{4 7 6 , 2 0 4 , 8 4 1}$
\end{tabular}

HEALTH SCIENCE CENTER / MEDICAL SCHOOL

\begin{tabular}{lrrrrr}
\hline Instruction/Research & $\$ 76,382,108$ & $\$ 95,673,445$ & $\$ 102,295,643$ & $\$ 116,949,551$ & $\$ 116,505,565$ \\
\hline Administration and Support & $\$ 5,076,837$ & $\$ 8,132,708$ & $\$ 6,263,326$ & $\$ 7,116,200$ & $\$ 6,317,189$ \\
\hline PO\&M & $\$ 1,800,847$ & $\$ 7,019,397$ & $\$ 7,391,135$ & $\$ 11,558,700$ & $\$ 6,893,395$ \\
\hline Library/Audio Visual & $\$ 3,043,160$ & $\$ 2,921,295$ & $\$ 2,587,261$ & $\$ 2,961,575$ & $\$ 2,818,268$ \\
\hline Teaching Hospital \& Clinics & $\$ 0$ & $\$ 0$ & $\$ 0$ & $\$ 0$ & $\$ 0$ \\
\hline Student Services, and Other & $\$ 0$ & $\$ 0$ & $\$ 0$ & $\$ 4,686$ & $\$ 533,836$ \\
\hline SUBTOTAL & $\$ 86,302,952$ & $\$ 113,746,845$ & $\$ 118,537,365$ & $\$ 138,590,712$ & $\$ 133,068,253$
\end{tabular}

\section{TOTAL} $\$ 374,342,907 \quad \$ 509,161,015 \quad \$ 512,525,594 \quad \$ 575,056,677 \quad \$ 609,273,094$

The table reports actual expenditures from revenues appropriated by the legislature for each fiscal year. The expenditures are classified by Program Component (e.g., Instruction/Research, PO\&M, Administration, etc...) for activities directly related to instruction, research and public service. The table does not include expenditures classified as non-operating expenditures (e.g., to service asset-related debts), and therefore excludes a small portion of the amount appropriated each year by the legislature. Note*: FY 2012-2013 reflects a change in reporting expenditures from prior years due to the new carry-forward reporting requirement as reflected in the 2013-2014 SUS Operating Budget Reports. Since these expenditures will now include carryforward expenditures, these data are no longer comparable to the current-year revenues reported in table 1A, or prior year expenditures in table 1B. This data is not adjusted for inflation.

Instruction \& Research: Includes expenditures for state services related to the instructional delivery system for advanced and professional education. Includes functions such as; all activities related to credit instruction that may be applied toward a postsecondary degree or certificate; non-project research and service performed to maintain professional effectives; individual or project research; academic computing support; academic source or curriculum development. Source: Operating Budget Summary - Expenditures by Program Activity (or Report 645). Administration \& Support Services: Expenditures related to the executive direction and leadership for university operations and those internal management services which assist and support the delivery of academic programs. Source: Operating Budget Summary - Expenditures by Program Activity (or Report 645). P0\&M: Plant Operations \& Maintenance expenditures related to the cleaning and maintenance of existing grounds, the providing of utility services, and the planning and design of future plant expansion and modification. Student Services: Includes resources related to physical, psychological, and social well-being of the student. Includes student service administration, social and cultural development, counseling and career guidance, financial aid, and student admissions and records. Other: includes Institutes and Research Centers, Radio/TV, Museums and Galleries, Intercollegiate Athletics, Academic Infrastructure Support Organizations. Source: Operating Budget Summary - Expenditures by Program Activity (or Report 645). 


\section{Section 1 - Financial Resources (continued)}

TABLE 1C. Funding per Full-Time Equivalent (FTE) Student

\begin{tabular}{lrrrrr} 
& $\mathbf{2 0 1 1 - 1 2}$ & $\mathbf{2 0 1 2 - 1 3}$ & $\mathbf{2 0 1 3 - 1 4}$ & $\mathbf{2 0 1 4 - 1 5}$ & $\mathbf{2 0 1 5 - 1 6}$ \\
\hline State Appropriation (GR \& Lottery) & $\$ 6,555$ & $\$ 4,986$ & $\$ 7,055$ & $\$ 7,834$ & $\$ 8,135$ \\
Tuition \& Fees (State-funded Aid) & $\$ 1,128$ & $\$ 1,112$ & $\$ 1,113$ & $\$ 1,000$ & $\$ 898$ \\
Tuition \& Fees (from Student) & $\$ 3,256$ & $\$ 3,756$ & $\$ 4,062$ & $\$ 4,437$ & $\$ 4,703$ \\
Other Trust Funds & $\$ 199$ & $\$ 0$ & $\$ 0$ & $\$ 0$ & $\$ 0$ \\
\hline TOTAL & $\$ 11,138$ & $\$ 9,854$ & $\mathbf{\$ 1 2 , 2 3 0}$ & $\mathbf{\$ 1 3 , 2 7 1}$ & $\mathbf{\$ 1 3 , 7 3 6}$
\end{tabular}

Notes: State Appropriations includes General Revenues and Lottery funds that are directly appropriated to the university as reported in Final Amendment Package. This does not include appropriations for special units (e.g., IFAS, Health Science Centers, and Medical Schools). Tuition and Fee revenues include tuition and tuition differential fee and E\&G fees (e.g., application, late registration, and library fees/fines) as reported on the from the Operating Budget 625 reports. Other local fees that do not support E\&G activities are not included here (see Board of Governors Regulation 7.003). To more accurately report the full contribution from the State, this table reports the state-funded financial aid separately from the tuition and fee payments universities receive from students (which may include federal financial aid dollars). The state-funded gift aid includes grants and scholarships as reported by universities to Board during the academic year in the State University Database (SUDS). Other Trust funds (e.g., Federal Stimulus for 2009-10 and 2010-11 only) as reported in Final Amendment Package. Full-time Equivalent enrollment is based on actual FTE, not funded FTE; and, does not include Health-Science Center funds or FTE. This data is based on the standard IPEDS definition of FTE, equal to 30 credit hours for undergraduates and 24 for graduates. This data is not adjusted for inflation.

\section{TABLE 1D. Cost per Bachelor's Degree}

\begin{tabular}{llllll} 
& $\mathbf{2 0 0 8 - 1 2}$ & $\mathbf{2 0 0 9 - 1 3}$ & $\mathbf{2 0 1 0 - 1 4}$ & $\mathbf{2 0 1 1 - 1 5}$ & $\mathbf{2 0 1 2 - 1 6}$ \\
\hline Cost to the Institution & $\$ 23,280$ & $\$ 24,340$ & $\$ 25,490$ & $\$ 26,990$ & $\$ 29,220$
\end{tabular}

\begin{tabular}{lccccc} 
[NEW] & $\mathbf{2 0 1 1 - 1 2}$ & $\mathbf{2 0 1 2 - 1 3}$ & $\mathbf{2 0 1 3 - 1 4}$ & $\mathbf{2 0 1 4 - 1 5}$ & $\mathbf{2 0 1 5 - 1 6}$ \\
\hline Net Tuition \& Fees per 120 Credit Hours &. &. & $\$ 14,490$ & $\$ 13,540$ & $\$ 13,170$
\end{tabular}

Notes: Cost to the Institution reports the Full expenditures include direct instructional, research and public service expenditures and the undergraduate portion of indirect expenditures (e.g., academic administration, academic advising, student services, libraries, university support, and Plant Operations and Maintenance). For each year, the full expenditures were divided by undergraduate fundable student credit hours to calculate the full expenditures per credit hour, and then multiplied by 30 credit hours to represent the annual undergraduate expenditures. The annual undergraduate expenditures for each of the four years was summed to provide an average undergraduate expenditures per (120 credit) degree. Source: State University Database System (SUDS), Expenditure Analysis: Report IV. Net Tuition \& Fees per 120 Credit Hours represents the average tuition and fees paid, after considering gift aid (e.g., grants, scholarships, waivers), by resident undergraduate FTICs who graduate from a program that requires 120 credit hours. This data includes an approximation for the cost of books. For more information about how this metric is calculated please see the methodology document at the Board's webpage, at: http://www.flbog.edu/about/budget/performance funding.php. This data is not adjusted for inflation. 


\section{Section 1 - Financial Resources (continued)}

TABLE 1E. University Other Budget Entities (Dollars in Millions)

2011-12 2012-13 2013-14

2014-15

2015-16

Auxiliary Enterprises

Revenues

Expenditures

Contracts \& Grants

Revenues

Expenditures

Local Funds

Revenues

Expenditures

Faculty Practice Plans

Revenues
Expenditures
$\$ 166,196,465 \quad \$ 179,066,877$

$\$ 136,665,180 \quad \$ 145,862,330$

$\$ 183,113,399$

$\$ 155,430,500$

$\$ 204,184,437$
$\$ 174,301,754$

$\$ 212,151,945$

$\$ 179,301,182$

$\begin{array}{lllll}\$ 253,155,100 & \$ 277,146,064 & \$ 280,938,042 & \$ 281,293,065 & \$ 310,861,310 \\ & & & & \\ \$ 309,631,943 & \$ 309,533,722 & \$ 322,685,124 & \$ 335,670,724 & \$ 366,958,129 \\ & & & \\ \$ 445,195,358 & \$ 447,961,430 & \$ 452,561,412 & \$ 434,954,904 & \$ 431,958,738 \\ & & & & \\ \$ 444,874,604 & \$ 451,386,947 & \$ 456,000,627 & \$ 435,058,108 & \$ 436,513,886 \\ & & & \\ \$ 194,997,543 & \$ 199,933,005 & \$ 212,976,074 & \$ 229,157,514 & \$ 237,163,547 \\ \$ 196,288,464 & \$ 198,051,785 & \$ 126,205,106 & \$ 229,678,555 & \$ 246,116,367\end{array}$

Notes: Revenues do not include transfers. Expenditures do not include non-operating expenditures. Auxiliary Enterprises are self-supported through fees, payments and charges. Examples include housing, food services, bookstores, parking services, health centers. Contract \& Grants resources are received from federal, state or private sources for the purposes of conducting research and public service activities. Local Funds are associated with student activity (supported by the student activity fee), student financial aid, concessions, intercollegiate athletics, technology fee, green fee, and student life \& services fee. Faculty Practice Plan revenues/receipts are funds generated from faculty practice plan activities. Faculty Practice Plan expenditures include all expenditures relating to the faculty practice plans, including transfers between other funds and/or entities. This may result in double counting in information presented within the annual report. Source: Operating Budget, Report 615. This data is not adjusted for inflation.

\section{TABLE 1F. Voluntary Support of Higher Education}

\begin{tabular}{cccccc} 
& $\mathbf{2 0 1 1 - 1 2}$ & $\mathbf{2 0 1 2 - 1 3}$ & $\mathbf{2 0 1 3 - 1 4}$ & $\mathbf{2 0 1 4 - 1 5}$ & $\mathbf{2 0 1 5 - 1 6}$ \\
\hline $\begin{array}{c}\text { Endowment Value } \\
\text { (\$1000s) }\end{array}$ & $\$ 334,100$ & $\$ 363,924$ & $\$ 417,335$ & $\$ 417,415$ & $\$ 395,324$ \\
\hline $\begin{array}{c}\text { Gifts Received } \\
\text { (\$1000s) }\end{array}$ & $\$ 43,600$ & $\$ 36,520$ & $\$ 37,419$ & $\$ 59,903$ & $\$ 45,583$ \\
\hline $\begin{array}{c}\text { Percentage of } \\
\text { Alumni Donors }\end{array}$ & $9.9 \%$ & $9.4 \%$ & $8.9 \%$ & $8.6 \%$ & $11.3 \%$ \\
\hline
\end{tabular}

Notes: Endowment value at the end of the fiscal year, as reported in the annual NACUBO Endowment Study. Gifts Received as reported in the Council for Aid to Education's Voluntary Support of Education (VSE) survey in the section entitled "Gift Income Summary," this is the sum of the present value of all gifts (including outright and deferred gifts) received for any purpose and from all sources during the fiscal year, excluding pledges and bequests. (There's a deferred gift calculator at www.cae.org/vse.) The present value of non-cash gifts is defined as the tax deduction to the donor as allowed by the IRS. Percentage of Alumni Donors as reported in the Council for Aid to Education's Voluntary Support of Education (VSE) survey in the section entitled "Additional Details," this is the number of alumni donors divided by the total number of alumni, as of the end of the fiscal year. "Alumni," as defined in this survey, include those holding a degree from the institution as well as those who attended the institution but did not earn a degree. This data is not adjusted for inflation. 


\section{Section 2 - Personnel}

TABLE 2A. Personnel Headcount (in Fall term only)

\begin{tabular}{lccccc} 
& $\mathbf{2 0 1 1}$ & $\mathbf{2 0 1 2}$ & $\mathbf{2 0 1 3}$ & $\mathbf{2 0 1 4}$ & $\mathbf{2 0 1 5}$ \\
\hline Full-time Employees & & & & & \\
\hline Tenured Faculty & 755 & 733 & 790 & 785 & 803 \\
Tenure-track Faculty & 387 & 375 & 335 & 329 & 331 \\
Non-Tenure Track Faculty & 501 & 521 & 922 & 695 & 820 \\
Instructors Without Faculty Status & 0 & 0 & 0 & 0 & 0 \\
Graduate Assistants/Associates & 0 & 0 & 0 & 0 & 0 \\
Non-Instructional Employees & 4,403 & 4,281 & 5,158 & 5,307 & 5,758 \\
\hline FULL-TIME SUBTOTAL & $\mathbf{6 , 0 4 6}$ & $\mathbf{5 , 9 1 0}$ & $\mathbf{7 , 2 0 5}$ & $\mathbf{7 , 1 1 6}$ & $\mathbf{7 , 7 1 2}$
\end{tabular}

\section{Part-time Employees}

\begin{tabular}{lccccc} 
Tenured Faculty & 47 & 56 & 26 & 39 & 32 \\
Tenure-track Faculty & 21 & 19 & 13 & 18 & 9 \\
Non-Tenure Track Faculty & 381 & 728 & 781 & 761 & 771 \\
Instructors Without Faculty Status & 0 & 0 & 0 & 0 & 1 \\
Graduate Assistants/Associates & 2,059 & 2,026 & 2,096 & 2,068 & 2,118 \\
Non-Instructional Employees & 211 & 778 & 82 & 73 & 62 \\
\hline PART-TIME SUBTOTAL & $\mathbf{2 , 7 1 9}$ & $\mathbf{3 , 6 0 7}$ & $\mathbf{2 , 9 9 8}$ & $\mathbf{2 , 9 5 9}$ & $\mathbf{2 , 9 9 3}$ \\
\hline \multicolumn{1}{c}{ TOTAL } & $\mathbf{8 , 7 6 5}$ & $\mathbf{9 , 5 1 7}$ & $\mathbf{1 0 , 2 0 3}$ & $\mathbf{1 0 , 0 7 5}$ & $\mathbf{1 0 , 7 0 5}$
\end{tabular}

Note: This table is based on the annual IPEDS Human Resources Survey, and provides full- and part-time medical and non-medical staff by faculty status and primary function/occupational activity. Tenured and Tenure-Track Faculty include those categorized within instruction, research, or public service. Non-Tenure Track Faculty includes adjunct faculty (on annual and less than annual contracts) and faculty on multi-year contracts categorized within instruction, research, or public service. Instructors Without Faculty Status includes postdoctoral research associates, and individuals hired as a staff member primarily to do research on a 3-year contract without tenure eligibility categorized within instruction, research, or public service. Non-Instructional Employees includes all executive, administrative and managerial positions regardless of faculty status; as well as, other support and service positions regardless of faculty status. Note: The universities vary on how they classify adjuncts (some include them as non-tenure track faculty while others do not consider them faculty and report them as instructors without faculty status) and part-time non-instructional employees. 


\section{Section 3 - Enrollment}

\section{TABLE 3A. Headcount Enrollment by Student Type and Level [REVISED]}

\begin{tabular}{lccccc} 
& Fall 2011 & Fall 2012 & Fall 2013 & Fall 2014 & Fall 2015 \\
\hline TOTAL & 47,362 & 47,854 & 48,330 & 48,578 & 48,984
\end{tabular}

\section{UNDERGRADUATE}

\begin{tabular}{lccccc}
\hline FTIC (Regular Admit) & 17,043 & 16,930 & 17,062 & 17,176 & 17,499 \\
FTIC (Profile Admit) & 196 & 173 & 155 & 202 & 205 \\
FCS AA Transfers & 9,284 & 9,498 & 9,416 & 9,172 & 9,108 \\
Other AA Transfers & 1,769 & 1,712 & 1,640 & 1,565 & 1,495 \\
Post-Baccalaureates & 0 & 0 & 0 & 1,110 & 1,025 \\
Other Undergraduates & 7,472 & 7,845 & 7,739 & 6,583 & 6,658 \\
\hline Subtotal & $\mathbf{3 5 , 7 6 4}$ & $\mathbf{3 6 , 1 5 8}$ & $\mathbf{3 6 , 0 1 2}$ & $\mathbf{3 5 , 8 0 8}$ & $\mathbf{3 5 , 9 9 0}$
\end{tabular}

GRADUATE

\begin{tabular}{lccccc}
\hline Master's & 6,395 & 6,481 & 6,806 & 6,950 & 7,160 \\
Research Doctoral & 2,362 & 2,336 & 2,294 & 2,226 & 2,229 \\
Professional Doctoral & 676 & 905 & 1,235 & 1,379 & 1,309 \\
\hline Dentistry & 0 & 0 & 0 & 0 & 0 \\
Law & 0 & 0 & 0 & 0 & 0 \\
Medicine & 502 & 549 & 620 & 658 & 699 \\
Nursing Practice & 27 & 30 & 43 & 89 & 129 \\
Pharmacy & 53 & 119 & 225 & 322 & 348 \\
Physical Therapist & 94 & 207 & 347 & 310 & 133 \\
Veterinary Medicine & 0 & 0 & 0 & 0 & 0 \\
Other & 0 & 0 & 0 & 0 & 0 \\
\hline Subtotal & $\mathbf{9 , 4 3 3}$ & $\mathbf{9 , 7 2 2}$ & $\mathbf{1 0 , 3 3 5}$ & $\mathbf{1 0 , 5 5 5}$ & $\mathbf{1 0 , 6 9 8}$
\end{tabular}

UNCLASSIFIED

\begin{tabular}{lccccc}
\hline HS Dual Enrolled & 0 & 0 & 42 & 14 & 24 \\
Other & 2,165 & 1,974 & 1,941 & 2,201 & 2,272 \\
\hline Subtotal & $\mathbf{2 , 1 6 5}$ & $\mathbf{1 , 9 7 4}$ & $\mathbf{1 , 9 8 3}$ & $\mathbf{2 , 2 1 5}$ & $\mathbf{2 , 2 9 6}$
\end{tabular}

Note: This table reports the number of students enrolled at the university by student type categories. The student type for undergraduates is based on the Type of Student at Time of Most Recent Admission. The student type for graduates is based on the degree that is sought and the student CIP code. Unclassified refers to a student who has not yet been formally admitted into a degree program but is enrolled. The methodology for this table was revised at the June 2017 Data Administrator Workshop. The change improves how post-baccalaureate undergraduate students are counted. 


\section{Section 3 - Enrollment (continued)}

\section{TABLE 3B. Full-Time Equivalent (FTE) Enrollment [REVISED]}

\begin{tabular}{lrrrrr} 
& $\mathbf{2 0 1 1 - 1 2}$ & $\mathbf{2 0 1 2 - 1 3}$ & $\mathbf{2 0 1 3 - 1 4}$ & $\mathbf{2 0 1 4 - 1 5}$ & $\mathbf{2 0 1 5 - 1 6}$ \\
\hline RESIDENT FUNDABLE & \multicolumn{5}{c}{} \\
\hline LOWER & 12,394 & 12,174 & 11,880 & 11,630 & 11,744 \\
UPPER & 19,512 & 19,609 & 18,973 & 18,653 & 18,538 \\
MASTERS (GRAD I) & 4,747 & 4,663 & 4,644 & 4,576 & 4,445 \\
DOCTORAL (GRAD II) & 1,308 & 1,285 & 1,261 & 1,261 & 1,161 \\
\cline { 2 - 6 } TOTAL & $\mathbf{3 7 , 9 6 1}$ & $\mathbf{3 7 , 7 3 0}$ & $\mathbf{3 6 , 7 5 8}$ & $\mathbf{3 6 , 1 2 0}$ & $\mathbf{3 5 , 8 8 8}$ \\
NON-RESIDENT FUNDABLE & & & & & \\
\hline LOWER & 672 & 845 & 1,028 & 1,181 & 1,419 \\
UPPER & 675 & 786 & 955 & 1,175 & 1,455 \\
MASTERS (GRAD I) & 723 & 857 & 1,078 & 1,226 & 1,477 \\
DOCTORAL (GRAD II) & 772 & 843 & 852 & 877 & 925 \\
TOTAL & $\mathbf{2 , 8 4 2}$ & $\mathbf{3 , 3 3 0}$ & $\mathbf{3 , 9 1 3}$ & $\mathbf{4 , 4 5 9}$ & $\mathbf{5 , 2 7 6}$ \\
TOTAL FUNDABLE & & & & & \\
\hline LOWER & 13,066 & 13,018 & 12,907 & 12,812 & 13,163 \\
UPPER & 20,187 & 20,395 & 19,928 & 19,828 & 19,993 \\
MASTERS (GRAD I) & 5,470 & 5,520 & 5,722 & 5,802 & 5,922 \\
DOCTORAL (GRAD II) & 2,080 & 2,128 & 2,113 & 2,138 & 2,085 \\
\cline { 2 - 6 } TOTAL & $\mathbf{4 0 , 8 0 3}$ & $\mathbf{4 1 , 0 6 0}$ & $\mathbf{4 0 , 6 7 1}$ & $\mathbf{4 0 , 5 8 0}$ & $\mathbf{4 1 , 1 6 3}$
\end{tabular}

TOTAL NON-FUNDABLE

\begin{tabular}{lrrrrr}
\hline LOWER & 418 & 473 & 536 & 607 & 632 \\
UPPER & 422 & 396 & 471 & 434 & 430 \\
MASTERS (GRAD I) & 250 & 314 & 441 & 594 & 630 \\
DOCTORAL (GRAD II) & 6 & 7 & 5 & 21 & 49 \\
\cline { 2 - 6 } TOTAL & $\mathbf{1 , 0 9 7}$ & $\mathbf{1 , 1 8 9}$ & $\mathbf{1 , 4 5 4}$ & $\mathbf{1 , 6 5 6}$ & $\mathbf{1 , 7 4 2}$ \\
TOTAL & & & & & \\
\hline LOWER & 13,484 & 13,491 & 13,443 & 13,419 & 13,795 \\
UPPER & 20,609 & 20,790 & 20,400 & 20,262 & 20,423 \\
MASTERS (GRAD I) & 5,720 & 5,833 & 6,164 & 6,396 & 6,553 \\
DOCTORAL (GRAD II) & 2,086 & 2,135 & 2,118 & 2,159 & 2,134 \\
\cline { 2 - 6 } TOTAL & $\mathbf{4 1 , 8 9 9}$ & $\mathbf{4 2 , 2 5 0}$ & $\mathbf{4 2 , 1 2 5}$ & $\mathbf{4 2 , 2 3 6}$ & $\mathbf{4 2 , 9 0 5}$
\end{tabular}

Notes: Full-time Equivalent (FTE) student is a measure of instructional activity that is based on the number of credit hours that students enroll by course level. Note about Revision: This table now reports FTE based on the US definition, which divides undergraduate credit hours by 30 and graduate credit hours by 24. Courses are reported by Universities to the Board of Governors in the Student Instruction File (SIF) as either fundable or non-fundable. In general, student credit hours are considered 'fundable' if they can be applied to a degree, and the associated faculty was paid from State appropriations. Totals are actual and may not equal the sum of reported student levels due to rounding of student level FTE. Total FTE are equal in tables 3B and 3C. 


\section{Section 3 - Enrollment (continued)}

\section{TABLE 3C. Full-Time Equivalent (FTE) Enrollment by Instructional Method [REVISED] 2011-12 2012-13 2013-14 2014-15 2015-16}

TRADITIONAL

$\begin{array}{lccccc}\text { LOWER } & 11,229 & 11,279 & 11,447 & 10,961 & 11,039 \\ \text { UPPER } & 14,934 & 14,528 & 13,949 & 13,452 & 13,501 \\ \text { MASTERS (GRAD I) } & 4,007 & 3,973 & 4,226 & 4,292 & 4,560 \\ \text { DOCTORAL (GRAD II) } & 1,996 & 2,033 & 1,997 & 2,008 & 1,950 \\ \text { TOTAL } & \mathbf{3 2 , 1 6 6} & \mathbf{3 1 , 8 1 3} & \mathbf{3 1 , 6 1 9} & \mathbf{3 0 , 7 1 4} & \mathbf{3 1 , 0 5 0}\end{array}$

DISTANCE LEARNING

\begin{tabular}{lccccc}
\hline LOWER & 2,189 & 2,079 & 1,904 & 2,362 & 2,739 \\
UPPER & 5,186 & 5,725 & 5,963 & 6,383 & 6,703 \\
MASTERS (GRAD I) & 1,509 & 1,656 & 1,717 & 1,920 & 1,960 \\
DOCTORAL (GRAD II) & 84 & 91 & 108 & 130 & 149 \\
TOTAL & $\mathbf{8 , 9 6 8}$ & $\mathbf{9 , 5 5 1}$ & $\mathbf{9 , 6 9 3}$ & $\mathbf{1 0 , 7 9 6}$ & $\mathbf{1 1 , 5 5 0}$ \\
& & & & & \\
HYBRID & & & & & \\
\hline LOWER & 66 & 133 & 92 & 95 & 18 \\
UPPER & 488 & 537 & 488 & 427 & 219 \\
MASTERS (GRAD I) & 205 & 205 & 221 & 184 & 34 \\
DOCTORAL (GRAD II) & 6 & 10 & 13 & 20 & 35 \\
TOTAL & 765 & 885 & 813 & 726 & 305
\end{tabular}

TOTAL

$\begin{array}{lccccc}\text { LOWER } & 13,484 & 13,491 & 13,443 & 13,419 & 13,795 \\ \text { UPPER } & 20,609 & 20,790 & 20,400 & 20,262 & 20,423 \\ \text { MASTERS (GRAD I) } & 5,720 & 5,834 & 6,164 & 6,396 & 6,553 \\ \text { DOCTORAL (GRAD II) } & 2,086 & 2,135 & 2,118 & 2,159 & 2,134 \\ \text { TOTAL } & \mathbf{4 1 , 8 9 9} & \mathbf{4 2 , 2 5 0} & \mathbf{4 2 , 1 2 5} & \mathbf{4 2 , 2 3 6} & \mathbf{4 2 , 9 0 5}\end{array}$

Note: Full-time Equivalent (FTE) student is a measure of instructional effort (and student activity) that is based on the number of credit hours that students enroll by course level. Note about Revision: FTE is now based on the standard national definition, which divides undergraduate credit hours by 30 and graduate credit hours by 24 . This data includes all instructional activity regardless of funding category.

Distance Learning is a course in which at least 80 percent of the direct instruction of the course is delivered using some form of technology when the student and instructor are separated by time or space, or both (per 1009.24(17), F.S.). In the future, this table will be able to split these FTE into two subgroups: $100 \%$ DL and $80-99 \%$ DL. Hybrid is a course where $50 \%$ to $79 \%$ of the instruction is delivered using some form of technology, when the student and instructor are separated by time or space, or both (per SUDS data element 2052). Traditional refers to instruction that occurs primarily in the classroom. This designation is defined as 'less than $50 \%$ of the direct instruction of the course is delivered using some form of technology when the student and instructor are separated by time, space or both. This designation can include activities that do not occur in a classroom (ie, labs, internships, practica, clinicals, labs, etc) - per SUDS data element 2052. Totals are actual and may not equal sum of reported student levels due to rounding of student level FTE. 


\section{Section 3 - Enrollment (continued)}

TABLE 3D. Headcount Enrollment by Military Status and Student Level

Fall $2011 \quad$ Fall $2012 \quad$ Fall $2013 \quad$ Fall $2014 \quad$ Fall 2015

\begin{tabular}{lccccc}
\hline MILITARY & \multicolumn{5}{c}{} \\
\hline Unclassified & 36 & 27 & 29 & 31 & 23 \\
Undergraduate & 933 & 1,014 & 1,025 & 1,079 & 1,149 \\
Master's (GRAD 1) & 153 & 178 & 187 & 189 & 228 \\
Doctoral (GRAD 2) & 26 & 27 & 18 & 23 & 22 \\
Subtotal & 1,148 & 1,246 & 1,259 & 1,322 & 1,422 \\
DEPENDENTS & & & & 0 & 0 \\
\hline Unclassified & 1 & 5 & 1 & 2 & 4 \\
Undergraduate & 174 & 190 & 198 & 199 & 200 \\
Master's (GRAD 1) & 14 & 15 & 20 & 16 & 14 \\
Doctoral (GRAD 2) & & 1 & 1 & 0 & 1 \\
Subtotal & 189 & 211 & $\mathbf{2 2 0}$ & $\mathbf{2 1 7}$ & $\mathbf{2 1 9}$ \\
NON-MILITARY & & & & & \\
\hline Unclassified & 2,128 & 1,942 & 1,953 & 2,182 & 2,269 \\
Undergraduate & 34,657 & 34,954 & 34,789 & 34,530 & 34,641 \\
Master's (GRAD 1) & 6,755 & 6,937 & 7,434 & 7,712 & 7,930 \\
Doctoral (GRAD 2) & 2,485 & 2,564 & 2,660 & 2,615 & 2,503 \\
Subtotal & $\mathbf{4 6 , 0 2 5}$ & $\mathbf{4 6 , 3 9 7}$ & $\mathbf{4 6 , 8 3 6}$ & $\mathbf{4 7 , 0 3 9}$ & $\mathbf{4 7 , 3 4 3}$ \\
\hline TOTAL & $\mathbf{4 7 , 3 6 2}$ & $\mathbf{4 7 , 8 5 4}$ & $\mathbf{4 8 , 3 1 5}$ & $\mathbf{4 8 , 5 7 8}$ & $\mathbf{4 8 , 9 8 4}$ \\
\hline
\end{tabular}

Note: This table provides trend data on the number of students enrolled based on their military status. Military includes students who were classified as Active Duty, Veterans, National Guard, or Reservist.. Eligible Dependents includes students who were classified as eligible dependents (dependents who received veteran's benefits). Non-Military includes all other students.

\section{TABLE 3E. University Access Rate: Undergraduate Enrollment with Pell Grant}

\begin{tabular}{lccccc} 
& Fall 2011 & Fall 2012 & Fall 2013 & Fall 2014 & Fall 2015 \\
\hline Pell Grant Recipients & 14,818 & 14,884 & 14,754 & 14,371 & 13,743 \\
\hline Percent with Pell Grant & $42.1 \%$ & $42.0 \%$ & $42.1 \%$ & $43.0 \%$ & $41.2 \%$
\end{tabular}

Note: This table reports the University's Access Rate, which is a measure of the percentage of undergraduate students who have received a federal Pell grant award during a given Fall term. The top row reports the number of students who received a Pell Grant award - this count excluded Non-Resident Aliens (NRA). The bottom row provides the percentage of eligible students that received a Pell Grant award. The denominator is based on students who had a record in the courses taken table during the term - and, excludes NRA, Post-Baccs (student type=P or S), and Fee_Class_Kind='I'. This metric is included in the Board of Governors Performance Based Funding Model - for more information see: http://www.flbog.edu/about/budget/performance funding.php. 


\section{Section 4 - Undergraduate Education}

\section{TABLE 4A. Baccalaureate Degree Program Changes in AY 2015-16}

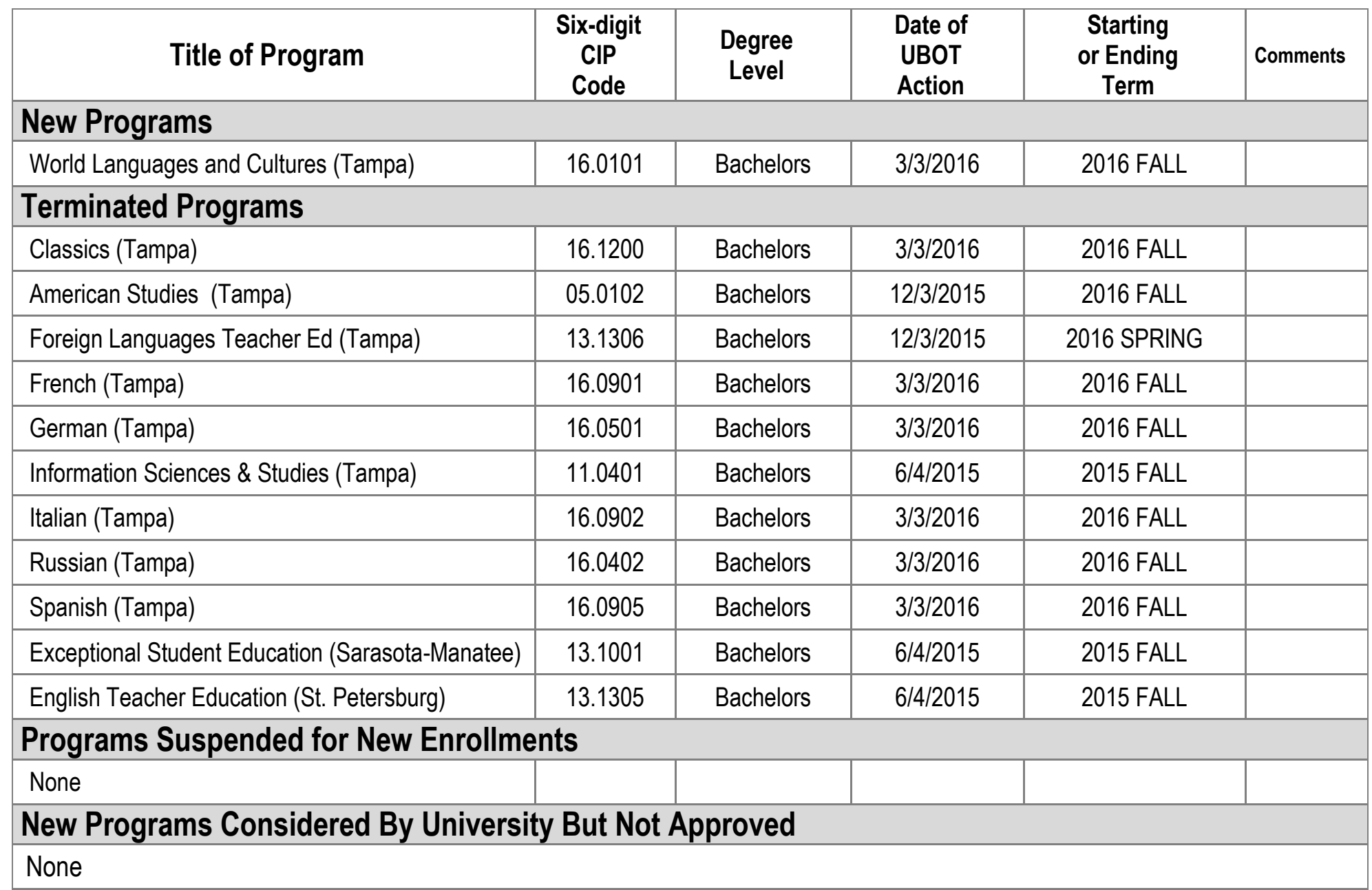

Note: This table does not include new majors or concentrations added under an existing degree program CIP Code. This table reports the new and terminated program changes based on Board action dates between May 5, 2015 and May 4, 2016.

New Programs are proposed new degree programs that have been completely through the approval process at the university and, if appropriate, the Board of Governors. Does not include new majors or concentrations added under an existing degree program CIP Code.

Terminated Programs are degree programs for which the entire CIP Code has been terminated and removed from the university's inventory of degree programs. Does not include majors or concentrations terminated under an existing degree program CIP Code if the code is to remain active on the academic degree inventory. Programs Suspended for New Enrollments are degree programs for which enrollments have been temporarily suspended for the entire CIP Code, but the program CIP Code has not been terminated. Does not include majors or concentrations suspended under an existing degree program CIP Code if the code is to remain active on the academic degree inventory and new enrollments in any active major will be reported. Programs included in this list may have been suspended for new enrollments sometime in the past and have continued to be suspended at least one term of this academic year. New Programs Considered by University But Not Approved includes any programs considered by the university board of trustees, or any committee of the board, but not approved for implementation. Also include any programs that were returned prior to board consideration by the university administration for additional development, significant revisions, or re-conceptualization; regardless of whether the proposal was eventually taken to the university board for approval. Count the returns once per program, not multiple times the proposal was returned for revisions, unless there is a total re-conceptualization that brings forward a substantially different program in a different CIP Code. 


\section{Section 4 - Undergraduate Education (continued)}

TABLE 4B. Full-time, First-Time-in-College (FTIC) Retention Rates

Retained in the Second Fall Term at Same University

\begin{tabular}{cccccc} 
& $\mathbf{2 0 1 1 - 1 2}$ & $\mathbf{2 0 1 2 - 1 3}$ & $\mathbf{2 0 1 3 - 1 4}$ & $\mathbf{2 0 1 4 - 1 5}$ & $\mathbf{2 0 1 5 - 1 6}$ \\
\hline Cohort Size & 4,027 & 4,508 & 4,490 & 4,650 & 4,783 \\
\hline $\begin{array}{c}\text { \% Retained } \\
\text { with Any GPA }\end{array}$ & $86 \%$ & $87 \%$ & $87 \%$ & $88 \%$ & $89 \%$ \\
\hline $\begin{array}{c}\text { \% Retained } \\
\text { with GPA 2.0 or higher }\end{array}$ & $83.8 \%$ & $84.5 \%$ & $85.3 \%$ & $85.1 \%$ & $86.1 \%$
\end{tabular}

Notes: Cohorts are based on undergraduate students who enter the institution in the Fall term (or Summer term and continue into the Fall term). Percent Retained with Any GPA is based on student enrollment in the Fall term following their first year. Percent Retained with GPA Above 2.0 is based on student enrollment in the Fall term following their first years for those students with a GPA of 2.0 or higher at the end of their first year (Fall, Spring, Summer). The most recent year of Retention data is based on preliminary data (SIFP file) that is comparable to the final data (SIF file) but may be revised in the following years based on changes in student cohorts. The 'Percent Retained with GPA Above 2.0' is also known as the 'Academic Progress Rate' and is included in the Board of Governors Performance Based Funding Model - for more information see:

http://www.flbog.edu/about/budget/performance funding.php.

\section{TABLE 4C. Full-time, First-Time-in-College (FTIC) Six-Year Graduation Rates}

\begin{tabular}{cccccc} 
Term of Entry & $\mathbf{2 0 0 6 - 1 2}$ & $\mathbf{2 0 0 7 - 1 3}$ & $\mathbf{2 0 0 8 - 1 4}$ & $\mathbf{2 0 0 9 - 1 5}$ & $\mathbf{2 0 1 0 - 1 6}$ \\
\hline Cohort Size & 4,271 & 3,980 & 4,259 & 4,241 & 4,928 \\
\hline \% Graduated & $57 \%$ & $64 \%$ & $67 \%$ & $68 \%$ & $66 \%$ \\
\hline \% Still Enrolled & $9 \%$ & $7 \%$ & $6 \%$ & $5 \%$ & $4 \%$ \\
\hline \% Success Rate & $66 \%$ & $71 \%$ & $72 \%$ & $73 \%$ & $70 \%$
\end{tabular}

Notes: Cohorts are based on FTIC undergraduate students who enter the institution in the Fall term (or Summer term and continue into the Fall term). Percent Graduated reports the percent of FTICs who graduated from the same institution within six years. This metric does not include students who enrolled as part-time students (in their first year), or who transfer into the institution. This metric complies with the requirements of the federal Student Right to Know Act that requires institutions to report the completion status at 150\% of normal time (or six years). Success Rate measures the percentage of an initial cohort of students who have either graduated or are still enrolled at the same university. This data should match the IPEDS Graduation Rate Survey data that is due in late February. 


\section{Section 4 - Undergraduate Education (continued) TABLE 4D. Graduation Rates for First-Time-in-College (FTIC) Students}

\begin{tabular}{|c|c|c|c|c|c|}
\hline 4 - Year Rates (FT only) & 2008-12 & $2009-13$ & 2010-14 & 2011-15 & 2012-16 \\
\hline Cohort Size & 4,259 & 4,241 & 4,928 & 4,027 & 4,508 \\
\hline Same University & $38 \%$ & $42 \%$ & $43 \%$ & $48 \%$ & $51 \%$ \\
\hline Other University in SUS & $1 \%$ & $2 \%$ & $2 \%$ & $2 \%$ & $2 \%$ \\
\hline Total from System & $39 \%$ & $43 \%$ & $45 \%$ & $51 \%$ & $53 \%$ \\
\hline
\end{tabular}

\begin{tabular}{lccccc}
$\mathbf{6}$ - Year Rates (FT \& PT) & $\mathbf{2 0 0 6 - 1 2}$ & $\mathbf{2 0 0 7 - 1 3}$ & $\mathbf{2 0 0 8 - 1 4}$ & $\mathbf{2 0 0 9 - 1 5}$ & $\mathbf{2 0 1 0 - 1 6}$ \\
\hline Cohort Size & 4,468 & 4,181 & 4,436 & 4,326 & 4,976 \\
Same University & $\mathbf{5 6 . 5 \%}$ & $\mathbf{6 3 . 2 \%}$ & $\mathbf{6 6 . 1} \%$ & $\mathbf{6 7 . 8 \%}$ & $\mathbf{6 6 . 3 \%}$ \\
\hline Other University in SUS & $4 \%$ & $3 \%$ & $4 \%$ & $4 \%$ & $5 \%$ \\
\hline Total from System & $60 \%$ & $67 \%$ & $70 \%$ & $72 \%$ & $71 \%$
\end{tabular}

Notes: Cohorts are based on undergraduate students who enter the institution in the Fall term (or Summer term and continue into the Fall term). First-timein-college (FTIC) cohort is defined as undergraduates entering in fall term (or summer continuing to fall) with fewer than 12 hours earned after high school graduation. The initial cohorts can be revised to remove students, who have allowable exclusions as defined by IPEDS, from the cohort. FTIC students who are enrolled in advanced graduate degree programs that do not award a Bachelor's degree are removed from the cohorts.

Graduates are students in the cohort who have graduated by the summer term in their fourth or sixth year. Degree data often includes 'late degrees' which are degrees that were awarded in a previous term, but reported to SUDS later; so, the most recent year of data in this table only provides preliminary graduation rate data that may change with the addition of "late degrees". Late degrees reported in conjunction with the IPEDS Graduation Rate Survey due in mid-February will be reflected in the following year.

Same University provides graduation rates for students in the cohort who graduated from the same institution.

Other University in SUS provides graduation rates for students in the cohort who graduated from a different State University System of Florida institution. These data do not report students in the cohort who did not graduate from the SUS, but did graduate from another institution outside the State University System of Florida.

The six-year graduation rate from the same university is included in the Board of Governors Performance Based Funding Model - for more information see: http://www.flbog.edu/about/budget/performance funding.php. 


\section{Section 4 - Undergraduate Education (continued)}

\section{TABLE 4E. Graduation Rates for AA Transfer Students from Florida College System}

\begin{tabular}{lccccc} 
Two - Year Rates & $\mathbf{2 0 1 0 - 1 2}$ & $\mathbf{2 0 1 1 - 1 3}$ & $\mathbf{2 0 1 2 - 1 4}$ & $\mathbf{2 0 1 3 - 1 5}$ & $\mathbf{2 0 1 4 - 1 6}$ \\
\hline Cohort Size & 2,484 & 2,609 & 2,527 & 2,558 & 2,558 \\
Same University & $28 \%$ & $28 \%$ & $29 \%$ & $28 \%$ & $30 \%$
\end{tabular}

\begin{tabular}{lccccc} 
Four - Year Rates & $\mathbf{2 0 0 8 - 1 2}$ & $\mathbf{2 0 0 9 - 1 3}$ & $\mathbf{2 0 1 0 - 1 4}$ & $\mathbf{2 0 1 1 - 1 5}$ & $\mathbf{2 0 1 2 - 1 6}$ \\
\hline Cohort Size & 2,536 & 2,333 & 2,484 & 2,609 & 2,527 \\
Same University & $66 \%$ & $69 \%$ & $67 \%$ & $67 \%$ & $68 \%$
\end{tabular}

Notes: AA Transfer cohort is defined as undergraduates entering in the fall term (or summer continuing to fall) and having earned an AA degree from an institution in the Florida College System. For comparability with FTIC cohorts, AA Transfer cohorts are based on undergraduate students who enter the institution in the Fall term (or Summer term and continue into the Fall term) and graduate from the same institution within two or four years.

\section{TABLE 4F. Graduation Rates for Other Transfer Students}

\begin{tabular}{lccccc}
$\mathbf{5}-$ Year Rates & $\mathbf{2 0 0 7 - 1 2}$ & $\mathbf{2 0 0 8 - 1 3}$ & $\mathbf{2 0 0 9 - 1 4}$ & $\mathbf{2 0 1 0 - 1 5}$ & $\mathbf{2 0 1 1 - 1 6}$ \\
\hline Cohort Size & 2,842 & 2,257 & 2,654 & 2,502 & 2,675 \\
Same University & $60 \%$ & $65 \%$ & $63 \%$ & $65 \%$ & $66 \%$
\end{tabular}

Notes: Other Transfer Students includes undergraduate students that transfer into a university who are not FTICs or AA Transfers. Cohorts are based on undergraduate students who enter the institution in the Fall term (or Summer term and continue into the Fall term) and graduate from the same institution within five years. 


\section{Section 4 - Undergraduate Education (continued)}

TABLE 4G. Baccalaureate Degrees Awarded

\begin{tabular}{lccccc} 
& $\mathbf{2 0 1 1 - 1 2}$ & $\mathbf{2 0 1 2 - 1 3}$ & $\mathbf{2 0 1 3 - 1 4}$ & $\mathbf{2 0 1 4 - 1 5}$ & $\mathbf{2 0 1 5 - 1 6}$ \\
\hline First Majors & 8,827 & 8,999 & 9,390 & 9,290 & 9,222 \\
Second Majors & 210 & 198 & 213 & 194 & 162 \\
\hline TOTAL & $\mathbf{9 , 0 3 7}$ & $\mathbf{9 , 1 9 7}$ & $\mathbf{9 , 6 0 3}$ & $\mathbf{9 , 4 8 4}$ & $\mathbf{9 , 3 8 4}$
\end{tabular}

Note: This table reports the number of degrees awarded by academic year. First Majors include the most common scenario of one student earning one degree in one Classification of Instructional Programs (CIP) code. In those cases where a student earns a baccalaureate degree under two different degree CIPs, a distinction is made between "dual degrees" and "dual majors." Also included in first majors are "dual degrees" which are counted as separate degrees (e.g., counted twice). In these cases, both degree CIPs receive a "degree fraction" of 1.0. Second Majors include all dual/second majors (e.g., degree CIP receive a degree fraction that is less than 1). The calculation of degree fractions is made according to each institution's criteria. The calculation for the number of second majors rounds each degree CIP's fraction of a degree up to 1 and then sums the total. Second Majors are typically used when providing degree information by discipline/CIP, to better conveys the number of graduates who have specific skill sets associated with each discipline.

\section{TABLE 4H. Baccalaureate Degrees in Programs of Strategic Emphasis (PSE)} [Includes Second Majors]

\begin{tabular}{lccccc} 
& $\mathbf{2 0 1 1 - 1 2}$ & $\mathbf{2 0 1 2 - 1 3}$ & $\mathbf{2 0 1 3 - 1 4}$ & $\mathbf{2 0 1 4 - 1 5}$ & $\mathbf{2 0 1 5 - 1 6}$ \\
\hline STEM & 1,897 & 2,071 & 2,064 & 2,055 & 2,212 \\
HEALTH & 708 & 895 & 1,158 & 1,596 & 1,727 \\
GLOBALIZATION & 284 & 249 & 289 & 268 & 276 \\
EDUCATION & 689 & 643 & 641 & 475 & 487 \\
GAP ANALYSIS & 787 & 699 & 747 & 783 & 834 \\
\hline SUBTOTAL & $\mathbf{4 , 3 6 5}$ & $\mathbf{4 , 5 5 7}$ & $\mathbf{4 , 8 9 9}$ & $\mathbf{5 , 1 7 7}$ & $\mathbf{5 , 5 3 6}$ \\
\hline PSE PERCENT OF TOTAL & $\mathbf{4 8 . 3} \%$ & $\mathbf{4 9 . 6 \%}$ & $\mathbf{5 1 . 0 \%}$ & $\mathbf{5 4 . 6 \%}$ & $\mathbf{5 9 . 0 \%}$
\end{tabular}

Notes: This is a count of baccalaureate majors for specific Programs of Strategic Emphasis, as determined by the Board of Governors staff with consultation with business and industry groups and input from universities. This is a count of baccalaureate degrees awarded within specific Programs of Strategic Emphasis, as determined by the Board of Governors staff with consultation with business and industry groups and input from universities - for more information see: http://www.flbog.edu/pressroom/strategic_emphasis/. The Board of Governors revised the list of Programs of Strategic Emphasis in November 2013, and the new categories were applied to the historical degrees. A student who has multiple majors in the subset of targeted Classification of Instruction Program codes will be counted twice (i.e., double-majors are included). 


\section{Section 4 - Undergraduate Education (continued)}

TABLE 4I. Baccalaureate Degrees Awarded to Underrepresented Groups

2011-12 2012-13 2013-14 2014-15 2015-16

Non-Hispanic Black

$\begin{array}{lccccc}\text { Number of Degrees } & 916 & 972 & 945 & 977 & 979 \\ \text { Percentage of Degrees } & 11 \% & 11 \% & 10 \% & 11 \% & 11 \%\end{array}$

Hispanic

$\begin{array}{lccccc}\text { Number of Degrees } & 1,390 & 1,433 & 1,645 & 1,728 & 1,777 \\ \text { Percentage of Degrees } & 16 \% & 16 \% & 18 \% & 19 \% & 20 \%\end{array}$

Pell-Grant Recipients

$\begin{array}{lccccc}\text { Number of Degrees } & 4,371 & 4,724 & 5,047 & 5,014 & 4,859 \\ \text { Percentage of Degrees } & 50 \% & 53 \% & 55 \% & 55 \% & 54 \%\end{array}$

Note: Non-Hispanic Black and Hispanic do not include students classified as Non-Resident Alien or students with a missing race code. Students who earn two distinct degrees in the same term are counted twice - whether their degrees are from the same six-digit CIP code or different CIP codes. Students who earn only one degree are counted once - even if they completed multiple majors or tracks. Percentage of Degrees is based on the number of baccalaureate degrees awarded to non-Hispanic Black and Hispanic students divided by the total degrees awarded - excluding those awarded to non-resident aliens and unreported.

Pell-Grant recipients are defined as those students who have received a Pell grant from any SUS Institution within six years of graduation - excluding those awarded to non-resident aliens, who are only eligible for Pell grants in special circumstances. Percentage of Degrees is based on the number of baccalaureate degrees awarded to Pell recipients, as shown above, divided by the total degrees awarded - excluding those awarded to non-resident aliens.

Notes on Trends: In 2007, the US Department of Education re-classified the taxonomy for self-reported race/ethnicity categories and allowed universities a two-year phase-in process before all institutions were required to report based on the new categories for the 2011-12 academic year. This reclassification will impact trends. 


\section{Section 4 - Undergraduate Education (continued)}

\section{TABLE 4J. Baccalaureate Degrees Without Excess Credit Hours}

\begin{tabular}{lc|cccc} 
& $\mathbf{2 0 1 1 - 1 2}$ & $\mathbf{2 0 1 2 - 1 3}$ & $\mathbf{2 0 1 3 - 1 4}$ & $\mathbf{2 0 1 4 - 1 5}$ & $\mathbf{2 0 1 5 - 1 6}$ \\
\hline FTIC & $57 \%$ & $54 \%$ & $61 \%$ & $65 \%$ & $70 \%$ \\
\hline AA Transfers & $60 \%$ & $68 \%$ & $72 \%$ & $74 \%$ & $84 \%$ \\
\hline Other Transfers & $40 \%$ & $52 \%$ & $58 \%$ & $58 \%$ & $72 \%$ \\
\hline TOTAL & $\mathbf{5 3 \%}$ & $\mathbf{5 8 . 2 0} \%$ & $\mathbf{6 3 . 8 7 \%}$ & $\mathbf{6 5 . 7 7 \%}$ & $\mathbf{7 5 . 5 8 \%}$
\end{tabular}

Notes: This table is based on statute 1009.286 (see link), and excludes certain types of student credits (e.g., accelerated mechanisms, remedial coursework, non-native credit hours that are not used toward the degree, non-native credit hours from failed, incomplete, withdrawn, or repeated courses, credit hours from internship programs, credit hours up to 10 foreign language credit hours for transfer students in Florida, and credit hours earned in military science courses that are part of the Reserve Officers' Training Corps (ROTC) program). This metric is not the same as the Excess Hours Surcharge, which has multiple cohorts with varying fee rates. This table reports the percentage of baccalaureate degrees awarded within $110 \%$ of the catalog hours required for a degree based on the Board of Governors Academic Program Inventory. This calculation is based on Hours To Degree data submitted by universities to the Board of Governors which excludes those who previously earned a baccalaureate degree.

Note*: Improvements were made to data collection process beginning with 2012-13 data to better account for high school dual enrolled credits that are exempt from the excess hour calculation. Also, 2012-13 data marked a slight methodological change in how the data is calculated. Each CIP code's required number of 'catalog hours' was switched to the officially approved hours as reported within the Board of Governors' Academic Program Inventory - instead of the catalog hours reported by the university on the HTD files.

\section{TABLE 4K. Undergraduate Course Offerings}

\begin{tabular}{lccccc} 
& Fall 2011 & Fall 2012 & Fall 2013 & Fall 2014 & Fall 2015 \\
\hline $\begin{array}{c}\text { Number of } \\
\text { Course Sections }\end{array}$ & 3,037 & 3,031 & 2,963 & 2,968 & 2,923 \\
$\begin{array}{l}\text { Percentage of Undergraduate Course Sections by } \\
\text { Class Size }\end{array}$ & & & \\
\hline Fewer than 30 Students & $59 \%$ & $59 \%$ & $58 \%$ & $62 \%$ & $62 \%$ \\
\hline 30 to 49 Students & $27 \%$ & $26 \%$ & $28 \%$ & $24 \%$ & $24 \%$ \\
\hline 50 to 99 Students & $11 \%$ & $11 \%$ & $10 \%$ & $10 \%$ & $10 \%$ \\
\hline 100 or More Students & $3 \%$ & $3 \%$ & $4 \%$ & $4 \%$ & $4 \%$
\end{tabular}

Notes: This data is based on Common Data Set (CDS) definitions. According to CDS, a "class section is an organized course offered for credit, identified by discipline and number, meeting at a stated time or times in a classroom or similar setting, and not a subsection such as a laboratory or discussion session. Undergraduate class sections are defined as any sections in which at least one degree-seeking undergraduate student is enrolled for credit. Exclude distance learning classes and noncredit classes and individual instruction such as dissertation or thesis research, music instruction, or one-to-one readings. Exclude students in independent study, co-operative programs, internships, foreign language taped tutor sessions, practicums, and all students in one-on-one classes. 


\section{Section 4 - Undergraduate Education (continued)}

TABLE 4L. Percentage of Undergraduate Credit Hours Taught by Instructor Type

\begin{tabular}{lccccc} 
& $\mathbf{2 0 1 1 - 1 2}$ & $\mathbf{2 0 1 2 - 1 3}$ & $\mathbf{2 0 1 3 - 1 4}$ & $\mathbf{2 0 1 4 - 1 5}$ & $\mathbf{2 0 1 5 - 1 6}$ \\
\hline Faculty & $68 \%$ & $66 \%$ & $67 \%$ & $65 \%$ & $65 \%$ \\
\hline Adjunct Faculty & $17 \%$ & $19 \%$ & $18 \%$ & $20 \%$ & $20 \%$ \\
\hline Graduate Students & $15 \%$ & $14 \%$ & $14 \%$ & $13 \%$ & $12 \%$ \\
\hline Other Instructors & $1 \%$ & $1 \%$ & $1 \%$ & $3 \%$ & $3 \%$
\end{tabular}

Note: The total number of undergraduate state fundable credit hours taught will be divided by the undergraduate credit hours taught by each instructor type to create a distribution of the percentage taught by each instructor type. Four instructor types are defined as faculty (pay plans 01,02 , and 22), OPS faculty (pay plan 06), graduate student instructors (pay plan 05), and others (all other pay plans). If a course has more than one instructor, then the university's reported allocation of section effort will determine the allocation of the course's total credit hours to each instructor. The definition of faculty varies for Tables $4 \mathrm{~L}, 4 \mathrm{M}$ and $4 \mathrm{~N}$. For Faculty Teaching Undergraduates, the definition of faculty is based on pay plans 01,02 , and 22.

\section{TABLE 4M. Student/Faculty Ratio}

\begin{tabular}{|c|c|c|c|c|c|}
\hline & Fall 2011 & Fall 2012 & Fall 2013 & Fall 2014 & Fall 2015 \\
\hline Ratio & 26 & 24 & 24 & 22 & 23 \\
\hline
\end{tabular}

\section{TABLE 4N. Professional Licensure/Certification Exams for Undergraduates}

\begin{tabular}{lccccc} 
Nursing: National Council Licensure Examination for Registered Nurses & & \\
& $\mathbf{2 0 1 1}$ & $\mathbf{2 0 1 2}$ & $\mathbf{2 0 1 3}$ & $\mathbf{2 0 1 4}$ & $\mathbf{2 0 1 5}$ \\
\hline Examinees & 210 & 184 & 186 & 189 & 193 \\
First-time Pass Rate & $95 \%$ & $93 \%$ & $91 \%$ & $86 \%$ & $90 \%$ \\
National Benchmark & $89 \%$ & $92 \%$ & $85 \%$ & $85 \%$ & $87 \%$
\end{tabular}

Note: Pass rate for first-time examinees for the National Council Licensure Examination for Registered Nurses (NCLEX-RN) are based on the performance of graduates of baccalaureate nursing programs. National benchmark data is based on Jan-Dec NCLEX-RN results for first-time examinees from students in US-educated baccalaureate degree programs as published by the National Council of State Boards of Nursing. 


\section{Section 4 - Undergraduate Education (continued)}

\section{TABLE 40. Post-Graduation Metrics}

\section{Percent of Bachelor's Graduates Employed or Continuing their Education, One Year After Graduation}

\begin{tabular}{lccccc} 
& $\mathbf{2 0 1 0 - 1 1}$ & $\mathbf{2 0 1 1 - 1 2}$ & $\mathbf{2 0 1 2 - 1 3}$ & $\mathbf{2 0 1 3 - 1 4}$ & $\mathbf{2 0 1 4 - 1 5}$ \\
\hline Employed (\$25,000+) or Enrolled & $n / a$ & $n / a$ & $65.3 \%$ & $67.2 \%$ & $69.6 \%$ \\
Employed (Full-time) or Enrolled & $69 \%$ & $70 \%$ & $74 \%$ & $76 \%$ & $78 \%$ \\
Percent Found & $91 \%$ & $89 \%$ & $92 \%$ & $93 \%$ & $93 \%$ \\
Number of States/Districts Searched & 1 & 36 & 38 & 39 & 41
\end{tabular}

Notes: Employed (Earning $\$ 25,000+$ ) or Enrolled is based on the number of recent baccalaureate graduates who are either employed, and earning at least $\$ 25,000$, or continuing their education within one year after graduation. Employed Full-Time or Enrolled is based on the number of recent baccalaureate graduates who are either employed full-time or continuing their education within one year after graduation. Full-time employment is based on those who earned at least as much as a full-time (40hrs a week) worker making minimum wage in Florida.

The employed data includes non-Florida data that is available from the Wage Record Interchange System 2 (known as "WRIS 2") and Federal employee data that is available from the Federal Employment Data Exchange System (FEDES) initiative. Military employment data was collected by the Board of Governors staff from university staff. Due to limitations in the data, the continuing enrollment data includes any enrollment the following year regardless of whether the enrollment was post-baccalaureate or not. Percent Found refers to the percentage of graduates found in the dataset - including those that did not earn wages above the full-time threshold and those who were found outside of the one-year window.

For more information about the methodology see: http://www.flbog.edu/about/budget/performance funding.php.

For more information about WRIS2 see: http://www.doleta.gov/performance/wris_2.cfm. For more information about FEDES see: http://www.ubalt.edu/fil/fedes/.

\section{Median Wages of Bachelor's Graduates Employed Full-time, One Year After Graduation}

\begin{tabular}{|c|c|c|c|c|c|}
\hline & $2010-11$ & $2011-12$ & $2012-13$ & $2013-14^{*}$ & $2014-15^{\star}$ \\
\hline 5th PERCENTILE WAGE & $\$ 17,300$ & $\$ 17,900$ & $\$ 18,400$ & 18,700 & 19,200 \\
\hline 25th PERCENTILE WAGE & $\$ 25,200$ & $\$ 25,500$ & $\$ 26,500$ & 27,400 & 28,500 \\
\hline MEDIAN WAGE & $\$ 33,200$ & $\$ 34,600$ & $\$ 35,200$ & $\$ 36,700$ & $\$ 38,000$ \\
\hline 75th PERCENTILE WAGE & $\$ 44,600$ & $\$ 44,000$ & $\$ 46,800$ & 48,400 & 51,100 \\
\hline 95th PERCENTILE WAGE & $\$ 64,900$ & $\$ 66,500$ & $\$ 66,600$ & 70,600 & 74,300 \\
\hline $\begin{array}{l}\text { Percent with FT wages } \\
\text { Number of States/Districts Searched }\end{array}$ & $\begin{array}{c}53 \% \\
1\end{array}$ & $\begin{array}{c}51 \% \\
1\end{array}$ & $\begin{array}{c}53 \% \\
1\end{array}$ & $\begin{array}{c}59 \% \\
39\end{array}$ & $\begin{array}{c}60 \% \\
41\end{array}$ \\
\hline
\end{tabular}

Notes: Wage data is based on annualized Unemployment Insurance (UI) wage data for those graduates who earned at least as much as a full-time employee making minimum wage in the fiscal quarter a full year after graduation. This $\mathrm{UI}$ wage data does not include individuals who are self-employed, employed out of state, employed by the military or federal government, or those without a valid social security number. This wage data includes graduates who were both employed and enrolled. Wages rounded to nearest hundreds. Percent with FT Wages refers to the percentage of graduates found in the dataset who earned wages above the full-time threshold.

Note*: The Board approved a change to this metric that uses wage data from all states that participate in the Wage Record Interchange System 2 (known as "WRIS 2"). This methodology change applies only to the wages for 2013-14 and 2014-15 baccalaureate recipients. 


\section{Section 5 - Graduate Education}

\section{TABLE 5A. Graduate Degree Program Changes in AY 2015-16}

\begin{tabular}{|c|c|c|c|c|c|c|}
\hline Title of Program & $\begin{array}{c}\text { Six-digit } \\
\text { CIP } \\
\text { Code }\end{array}$ & $\begin{array}{l}\text { Degree } \\
\text { Level }\end{array}$ & $\begin{array}{l}\text { Date of } \\
\text { UBOT } \\
\text { Action }\end{array}$ & $\begin{array}{l}\text { Starting } \\
\text { or Ending } \\
\text { Term }\end{array}$ & $\begin{array}{l}\text { Date of } \\
\text { Board of } \\
\text { Governors } \\
\text { Action }\end{array}$ & Comments \\
\hline \multicolumn{7}{|l|}{ New Programs } \\
\hline Nurse Anesthetist (Tampa) & 51.3804 & Masters & $6 / 4 / 2015$ & 2015 FALL & & \\
\hline $\begin{array}{l}\text { Pharmaceutical Nanotechnology } \\
\text { (Tampa) }\end{array}$ & 51.2099 & Masters & $9 / 16 / 2015$ & 2016 SPRING & & \\
\hline \multicolumn{7}{|l|}{ Terminated Programs } \\
\hline American Studies (Tampa) & 5.0102 & Masters & $12 / 3 / 2015$ & 2016 FALL & & \\
\hline $\begin{array}{l}\text { Exceptional Student Education } \\
\text { (Sarasota-Manatee) }\end{array}$ & 13.1001 & Masters & $6 / 4 / 2015$ & 2015 FALL & & \\
\hline \multicolumn{7}{|c|}{ Programs Suspended for New Enrollments } \\
\hline Journalism (Tampa) & 9.0401 & Masters & - & 2015 FALL & & \\
\hline Social Work (Tampa) & 44.0701 & $\begin{array}{l}\text { Research } \\
\text { Doctorate }\end{array}$ & - & 2016 SPRING & & \\
\hline \multicolumn{7}{|c|}{ New Programs Considered By University But Not Approved } \\
\hline
\end{tabular}

Note: This table does not include new majors or concentrations added under an existing degree program CIP Code. This table reports the new and terminated program changes based on Board action dates between May 5, 2015 and May 4, 2016.

New Programs are proposed new degree programs that have been completely through the approval process at the university and, if appropriate, the Board of Governors. Does not include new majors or concentrations added under an existing degree program CIP Code.

Terminated Programs are degree programs for which the entire CIP Code has been terminated and removed from the university's inventory of degree programs. Does not include majors or concentrations terminated under an existing degree program CIP Code if the code is to remain active on the academic degree inventory.

Programs Suspended for New Enrollments are degree programs for which enrollments have been temporarily suspended for the entire CIP Code, but the program CIP Code has not been terminated. Does not include majors or concentrations suspended under an existing degree program CIP Code if the code is to remain active on the academic degree inventory and new enrollments in any active major will be reported. Programs included in this list may have been suspended for new enrollments sometime in the past and have continued to be suspended at least one term of this academic year.

New Programs Considered by University But Not Approved includes any programs considered by the university board of trustees, or any committee of the board, but not approved for implementation. Also include any programs that were returned prior to board consideration by the university administration for additional development, significant revisions, or re-conceptualization; regardless of whether the proposal was eventually taken to the university board for approval. Count the returns once per program, not multiple times the proposal was returned for revisions, unless there is a total re-conceptualization that brings forward a substantially different program in a different CIP Code. 


\section{Section 5 - Graduate Education (continued)}

TABLE 5B. Graduate Degrees Awarded

\begin{tabular}{lccccc} 
& $\mathbf{2 0 1 1 - 1 2}$ & $\mathbf{2 0 1 2 - 1 3}$ & $\mathbf{2 0 1 3 - 1 4}$ & $\mathbf{2 0 1 4 - 1 5}$ & $\mathbf{2 0 1 5 - 1 6}$ \\
\hline First Majors & 3,159 & 3,209 & 3,401 & 3,773 & 3,918 \\
Second majors & 0 & 0 & 0 & 0 & 0 \\
\hline TOTAL & $\mathbf{3 , 1 5 9}$ & $\mathbf{3 , 2 0 9}$ & $\mathbf{3 , 4 0 1}$ & $\mathbf{3 , 7 7 3}$ & $\mathbf{3 , 9 1 8}$ \\
\hline Masters and Specialist (1st majors) & 2,742 & 2,761 & 2,855 & 3,172 & 3,214 \\
Research Doctoral (1st majors) & 271 & 295 & 330 & 321 & 314 \\
Professional Doctoral (1st majors) & 146 & 153 & 216 & 280 & 390 \\
\hline Dentistry & 0 & 0 & 0 & 0 & 0 \\
Law & 0 & 0 & 0 & 0 & 0 \\
Medicine & 112 & 106 & 120 & 124 & 172 \\
\hline Nursing Practice & 6 & 5 & 0 & 12 & 17 \\
Pharmacy & 0 & 0 & 0 & 49 & 53 \\
Physical Therapist & 28 & 42 & 90 & 95 & 148 \\
\hline Veterinary Medicine & 0 & 0 & 0 & 0 & 0 \\
Other Professional Doctorate & 0 & 0 & 0 & 0 & 0
\end{tabular}

Note: This table reports the total number of graduate level degrees that were awarded by academic year as well as the number by level. The table provides a breakout for some of the Professional Doctoral degrees.

\section{TABLE 5C. Graduate Degrees Awarded in Areas of Strategic Emphasis}

\section{[Includes Second Majors]}

\begin{tabular}{lccccc} 
& $\mathbf{2 0 1 1 - 1 2}$ & $\mathbf{2 0 1 2 - 1 3}$ & $\mathbf{2 0 1 3 - 1 4}$ & $\mathbf{2 0 1 4 - 1 5}$ & $\mathbf{2 0 1 5 - 1 6}$ \\
\hline STEM & 730 & 845 & 932 & 1,088 & 1,167 \\
\hline HEALTH & 729 & 762 & 838 & 1,050 & 1,196 \\
\hline GLOBALIZATION & 31 & 29 & 25 & 42 & 31 \\
\hline EDUCATION & 572 & 493 & 453 & 455 & 413 \\
\hline GAP ANALYSIS & 66 & 90 & 97 & 107 & 116 \\
\hline SUBTOTAL & 2,128 & 2,219 & 2,345 & 2,742 & 2,923 \\
\hline PSE PERCENT OF TOTAL & $\mathbf{6 7 . 3 6 \%}$ & $\mathbf{6 9 . 1 5 \%}$ & $\mathbf{6 8 . 9 5 \%}$ & $\mathbf{7 2 . 6 7 \%}$ & $\mathbf{7 4 . 6 0 \%}$
\end{tabular}

Notes: This is a count of graduate degrees awarded within specific Areas of Strategic Emphasis, as determined by the Board of Governors staff with consultation with business and industry groups and input from universities. This is a count of graduate degrees awarded within specific Programs of Strategic Emphasis, as determined by the Board of Governors staff with consultation with business and industry groups and input from universities - for more information see: http://www.flbog.edu/pressroom/strategic emphasis/. The Board of Governors revised the list of Programs of Strategic Emphasis in November 2013, and the new categories were applied to the historical degrees. A student who has multiple majors in the subset of targeted Classification of Instruction Program codes will be counted twice (i.e., double-majors are included). Note: The denominator used in the percentage includes second majors. 


\section{Section 5 - Graduate Education (continued)}

TABLE 5D. Professional Licensure Exams for Graduate Programs

Medicine: US Medical Licensing Exam - Step 1 (for 2nd year MD students)

\begin{tabular}{lccccc} 
& $\mathbf{2 0 1 2}$ & $\mathbf{2 0 1 3}$ & $\mathbf{2 0 1 4}$ & $\mathbf{2 0 1 5}$ & $\mathbf{2 0 1 6}$ \\
\hline Examinees & 125 & 145 & 147 & 168 & 155 \\
First-time Pass Rate & $91 \%$ & $96 \%$ & $95 \%$ & $97 \%$ & $94 \%$ \\
National Benchmark & $96 \%$ & $97 \%$ & $96 \%$ & $96 \%$ & $96 \%$
\end{tabular}

Medicine: US Medical Licensing Exam - Step 2 Clinical Knowledge (for $4^{\text {th }}$ year MD students)

\begin{tabular}{lccccc} 
& $\mathbf{2 0 1 1 - 1 2}$ & $\mathbf{2 0 1 2 - 1 3}$ & $\mathbf{2 0 1 3 - 1 4}$ & $\mathbf{2 0 1 4 - 1 5}$ & $\mathbf{2 0 1 5 - 1 6}$ \\
\hline Examinees & 115 & 152 & 136 & 157 & 176 \\
First-time Pass Rate & $99 \%$ & $100 \%$ & $98 \%$ & $97 \%$ & $99 \%$ \\
National Benchmark & $98 \%$ & $98 \%$ & $97 \%$ & $95 \%$ & $96 \%$
\end{tabular}

Medicine: US Medical Licensing Exam - Step 2 Clinical Skills (for $4^{\text {th }}$ year MD students)

\begin{tabular}{lccccc} 
& $\mathbf{2 0 1 1 - 1 2}$ & $\mathbf{2 0 1 2 - 1 3}$ & $\mathbf{2 0 1 3 - 1 4}$ & $\mathbf{2 0 1 4 - 1 5}$ & $\mathbf{2 0 1 5 - 1 6}$ \\
\hline Preliminary \\
\hline First-time Pass Rate & 100 & 128 & 142 & 131 & 135 \\
National Benchmark & $98 \%$ & $99 \%$ & $91 \%$ & $96 \%$ & $96 \%$ \\
& $97 \%$ & $98 \%$ & $96 \%$ & $96 \%$ & $97 \%$
\end{tabular}

Physical Therapy: National Physical Therapy Examinations

\begin{tabular}{lccccc} 
& $\mathbf{2 0 0 9 - 1 1}$ & $\mathbf{2 0 1 0 - 1 2}$ & $\mathbf{2 0 1 1 - 1 3}$ & $\mathbf{2 0 1 2 - 1 4}$ & $\mathbf{2 0 1 3 - 1 5}$ \\
\hline Examinees & 96 & 93 & 92 & 87 & 98 \\
First-time Pass Rate & $87 \%$ & $90 \%$ & $94 \%$ & $97 \%$ & $95 \%$ \\
National Benchmark & $89 \%$ & $88 \%$ & $89 \%$ & $90 \%$ & $91 \%$
\end{tabular}

Note: Note on Benchmarks: The USMLE national exam pass rates, for the MD degree from US institutions, is reported online by the National Board of Medical Examiners (NBME). Three-year average pass rates for first-time examinees on the National Physical Therapy Examinations are reported, rather than annual averages, because of the relatively small cohort sizes. Due to changes in accreditation policy, the National Board for Certification in Occupational Therapy (NBCOT) examinations no longer report first-time pass rates. The reported pass rates are now 'New Graduates' pass rates and represent the ultimate pass rate, or the percentage of students who passed regardless of how many times the exam was taken. The Dental Board and Occupational Therapy exams are national standardized examinations not licensure examinations. Students who wish to practice in Florida must also take a licensure exam. 


\section{Section 6 - Research and Economic Development TABLE 6A. Research and Development}

2010-11 2011-12 2012-13 2013-14 2014-15

\section{R\&D Expenditures}

Total (S\&E and non-S\&E)

(\$1,000s)

Federally Funded

(\$1,000s)

$$
\$ 400,679
$$

$\$ 245,410$

Percent Funded

From External Sources

$70 \%$

$\$ 360,323$

Total R\&D Expenditures

Per Full-Time, Tenured,

Tenure-Earning Faculty Member
$2011-12$

$\$ 451,259$

$\$ 467,355$

$\$ 496,575$

$\$ 494,241$

$\$ 239,902$

$\$ 228,460$

$\$ 225,564$

$\$ 221,045$

$62 \%$

$59 \%$

$60 \%$

$55 \%$

\section{Technology Transfer}

Invention Disclosures

Licenses \& Options Executed

Licensing Income

Received (\$)

Number of Start-Up Companies

Utility Patents Issued
2010-11

2011-12

2012-13

177

185

$\$ 421,801$

$\$ 441,400$

$\$ 443,663$

172

2013-14

2014-15

185

\section{Unity Patents Issued}

36

52

75

$\$ 1,390,871 \quad \$ 1,243,425$

8
10
$\$ 1,802,233$

9
91

190

91

$\$ 2,455,124$

119

Notes: R\&D Expenditures are based on the National Science Foundation's annual Survey of R\&D Expenditures at Universities and Colleges (data include Science \& Engineering and non-Science \& Engineering awards). Percent Funded from External Sources is defined as funds from federal, private industry and other sources (non-state and non-institutional funds). Total R\&D expenditures are divided by fall, full-time tenured/tenure-track faculty as reported to IPEDS (FGCU includes both tenured/tenure-track and non-tenure/track faculty). The fall faculty year used will align with the beginning of the fiscal year (e.g., 2007 FY R\&D expenditures are divided by fall 2006 faculty). Invention Disclosures reports the number of disclosures made to the university's Office of Technology Commercialization to evaluate new technology - as reported on the Association of University Technology Managers Annual (AUTM) annual Licensing Survey. Licenses \& Options Executed that were executed in the year indicated for all technologies - as reported by AUTM. Licensing Income Received refers to license issue fees, payments under options, annual minimums, running royalties, termination payments, amount of equity received when cashed-in, and software and biological material end-user license fees of $\$ 1,000$ or more, but not research funding, patent expense reimbursement, valuation of equity not cashed-in, software and biological material end-user license fees of less than $\$ 1,000$, or trademark licensing royalties from university insignia - as reported on the AUTM survey. Number of Start-up Companies that were dependent upon the licensing of University technology for initiation - as reported on the Association of University Technology Managers Annual Licensing Survey. Utility Patents Issued by the United States Patent and Trademark Office (USPTO) by Calendar year - this does not include design, plant or other patent types. 


\section{Section 6 - Research and Economic Development (continued)}

\section{TABLE 6B. Centers of Excellence}

\begin{tabular}{|c|c|c|c|}
\hline Name of Center: & Center for Drug Discovery and Innovation (CDDI) & \multirow{2}{*}{$\begin{array}{l}\text { Cumulative } \\
\text { (since inception } \\
\text { to June 2016) }\end{array}$} & \multirow{2}{*}{$\begin{array}{l}\text { Fiscal Year } \\
2015-16\end{array}$} \\
\hline Year Created: & 2007 & & \\
\hline \multicolumn{4}{|c|}{$\begin{array}{l}\text { Research Effectiveness } \\
\text { Only includes data for activities directly associated with the Center. Does not include the non-Center activities for faculty who are } \\
\text { associated with the Center. }\end{array}$} \\
\hline \multicolumn{2}{|c|}{ Number of Competitive Grants Applied For } & 242 & 22 \\
\hline \multicolumn{2}{|c|}{ Value of Competitive Grants Applied For (\$) } & $\$ 189,109,484$ & $\$ 23,971,125$ \\
\hline \multicolumn{2}{|c|}{ Number of Competitive Grants Received } & 98 & 17 \\
\hline \multicolumn{2}{|c|}{ Value of Competitive Grants Received (\$) } & $\$ 51,857,018$ & $\$ 7,230,600$ \\
\hline \multicolumn{2}{|c|}{ Total Research Expenditures (\$) } & $\$ 21,392,621$ & $\$ 874,560$ \\
\hline \multicolumn{2}{|c|}{$\begin{array}{l}\text { Number of Publications in Refereed Journals } \\
\text { From Center Research }\end{array}$} & 214 & 9 \\
\hline \multicolumn{2}{|c|}{ Number of Invention Disclosures } & 61 & 7 \\
\hline \multicolumn{2}{|c|}{ Number of Licenses/Options Executed } & 12 & 0 \\
\hline \multicolumn{2}{|c|}{ Licensing Income Received (\$) } & $\$ 172,071$ & $\$ 8,000$ \\
\hline \multicolumn{4}{|c|}{$\begin{array}{l}\text { Collaboration Effectiveness } \\
\text { Only reports on relationships that include financial or in-kind support. }\end{array}$} \\
\hline \multicolumn{2}{|c|}{ Collaborations with Other Postsecondary Institutions } & 81 & 5 \\
\hline \multicolumn{2}{|c|}{ Collaborations with Private Industry } & 109 & 4 \\
\hline \multicolumn{2}{|c|}{ Collaborations with K-12 Education Systems/Schools } & 51 & 0 \\
\hline \multicolumn{2}{|c|}{$\begin{array}{l}\text { Undergraduate and Graduate Students Supported } \\
\text { with Center Funds }\end{array}$} & 136 & 28 \\
\hline \multicolumn{4}{|c|}{ Economic Development Effectiveness } \\
\hline \multicolumn{2}{|c|}{$\begin{array}{l}\text { Number of Start-Up companies } \\
\text { with a physical presence, or employees, in Florida }\end{array}$} & 1 & 0 \\
\hline \multicolumn{2}{|c|}{$\begin{array}{l}\text { Jobs Created By Start-Up Companies } \\
\text { Associated with the Center }\end{array}$} & 5 & 0 \\
\hline \multicolumn{2}{|c|}{ Specialized Industry Training and Education } & 14 & 0 \\
\hline \multicolumn{2}{|c|}{$\begin{array}{l}\text { Private-sector Resources Used to Support } \\
\text { the Center's Operations }\end{array}$} & 0 & 0 \\
\hline
\end{tabular}




\section{Section 6 - Research and Economic Development (continued) TABLE 6B. Centers of Excellence (continued)}

\section{Name of Center}

Narrative Comments [Most Recent Year]: 2015-16

(1) On June 1, 2016, Dr. Gary Daughdrill was awarded an NIH 5 year R01 grant totaling $\$ 1,610,260$, with the primary focus of the study on the interaction between disordered and ordered proteins domains and the cellular consequences.

(2) On June14, 2016, Dr. Michael White was awarded an NIH 5 year R01 grant totaling $\$ 2,643,135$ to further research on malaria related diseases. Other CDDI faculty members that are collaborators on this grant include Assistant Research Professor, Dr. Elena Suvorova and Research Associate, Dr. Anatoli Naumov. 